\title{
Econometric Study of Loan Classification of Commercial Banks in Bangladesh
}

\author{
Bijoy Chandra Das ${ }^{1}$, Soma Rani Sutradhar ${ }^{2}$ \\ ${ }^{1}$ Lecturer, Department of Finance and Banking, Jatiya Kabi Kazi Nazrul Islam \\ UniversityTrishal, Mymensingh-2220 \\ ${ }^{2}$ Assistant Professor, Department of Economics, Jatiya Kabi Kazi Nazrul Islam \\ UniversityTrishal, Mymensingh-2220
}

\begin{abstract}
This research intends to exemplify the loan classification of commercial banks in Bangladesh. The study area is selected on commercial banks of Bangladesh. After liberation, our banking business had been performing well but very recent time most of the banks face a problem of loan classification. So they loss some profit and fall under trouble for the loan run. We know that there are 56 commercial banks in Bangladesh. Deposit collection and lending are the main function of these banks. The study is conducted on only five commercial banks of Bangladesh. Last 10 years data of the selected banks are considered to accomplish the study. This research focuses on the major challenges of good loan that obstruct smooth development of Bangladesh. This study conveys the message that if the loan classification is reduced and good loan culture is created, the banking sector will flourish very fast way.
\end{abstract}

Key words: Loan, Non-performing loan, Loan classification, Deposit, Provision

\section{INTRODUCTION}

Effective flow of investments and savings culture is the precondition of the economic development of any country. As a developing country, Bangladesh faces several obstacles such as bad loan culture as well as underdeveloped capital market which mostly depend on the mobilization of the savings and granting credit facilities to the investors by the commercial banks. The performance of the financial sector of our country depends on the performance of commercial banks. If we look the previous decade's performance of our financial sector, we will examine that our financial sector faces the high percentage of non-performing loans (NPLs) or loan classification. It is known to that entire nonperforming loans shrink the profitability of banks. Banks do not earn interest income from the classified loans. Non-performing loans decrease the loan able fund of the banks and it stops the recycling banking business. For offsetting bad debt loan, Banks always try to create a reserve fund which is created from interest income of the banks. Bank needs to create high percentage of provision to cover high percentage of non-performing loans. All kinds of non-performing loans reduces the profitability of the banks and banks face low capital base problem which impact on our banking sector badly. From the information of banking sector of our country, we see that the ratio of classified loan to total loans of all the banks had been declined from 34.90 percent to 10 percent in December 2012. In 2014, the ratio had been increased to 11.9 percent.

Loan classification refers to the loan which is never be collected by the banks. Every bank always tries to maintain the good loan culture but in some cases it is not possible. There are several reasons for the classification of loan. Loan repayment depends on the willingness and capability of the borrowers. In Bangladesh, the political situation is fully robust. So banks face several obstacles from this sector. 
As a researcher, we read and work on several topics such as business, finance as well as economics and some practical knowledge. For applying the knowledge attained from previous knowledge, this econometric study on loan classification of selected commercial banks has been conducted. The main purpose of this research work is to recognize the impact the loan classification on the profitability of the commercial banks. The goal of this study is to give the opportunity to the readers to know something in real time situations of loan classification.

\subsection{Rational of the research}

This research will be attempted to focus on econometric study of loan classification of commercial banks in Bangladesh. There are several reasons such as political, demographical, previous history and negative attitudes of borrowers to classify the loan of commercial banks. At the beginning of the banking business of Bangladesh, loan classification was presented in the book to gather knowledge about this theoretically but now a day, it is very common word to the people of Bangladesh. As a result of this culture, every bank counts loss regularly and government deprives from tax income. Loan officers are not efficient enough to assess the borrowers and the regulator of banks fails to control the loan classification of the banks. If Bangladesh Bank takes strong attempts against the defaulters then loan classification can be minimized. On the other hand, our government should take effective steps to overcome this problem.

It is inspiring that Bangladesh Bank takes as well as government take some steps to avoid this culture but these are enough. The important proponents of the policy paradigm may be the following:

- Loan disclosure and supervisory review process should be conducted effectively.

- Bangladesh Bank should complete the audit effectively.

- Bangladesh Bank should take efficient step against the loan defaulters.

- $\quad$ Strong monitoring system should be ensured by higher authority of the banks.

- Policy provisions to support the good loan.

- $\quad$ Create friendly and favorable culture of repayment of Ioan.

\subsection{Objective of the Research}

This research is conducted on five commercial banks such as AB Bank Limited, Prime Bank Limited, EXIM Bank Limited, The City Bank Limited, United Commercial Bank Limited. It is accomplished on the "Econometric study of loan classifications of commercial banks in Bangladesh." This study also includes the information on the overview of five commercial banks, theoretical analysis of loan classification and legal framework of Bangladesh on loan classification.

\section{Specific Objectives:}

The fundamental purpose of this research work is to get enough knowledge about the real scenario of loan classification of commercial banks in Bangladesh.

\section{Broad Objectives:}

The specific objectives of this report are:

- Theoretical analysis of loan classification.

- Correlation analysis of different factors of financial data.

- Ratio analysis of the different accounting heads.

- Trend analysis of the banks ratios.

- Regression analysis of financial data.

- To identify the potential and problems loan classification of the banks.

\section{Hypothesis:}

- Enhancement of loan does not have any influence on loan classification.

- Enhancement of loan influences on loan classification.

- To find out the relationship among loan, deposit, cash in hand (CIH) and balance with other banks (BWOB) the following regression equation has been built. 


$$
\begin{aligned}
Y= & B_{1}+B_{2} \times X_{2}+B_{3} \times X_{3}+B_{4} \times X_{4}+\mu \\
& \text { Here, } \\
Y & =\text { Toal Amount of Loan } \\
X_{2} & =\text { deposit } \\
X_{3} & =\text { Cash In Hand } \\
X_{4} & =\text { Balance with otherbanks } \\
B_{1} & =\text { estimator } \\
B_{2} & =\text { Co-efficient of deposit } \\
B_{3} & =\text { Co- efficient of } \text { CIH } \\
B_{4} & =\text { Co- efficient of } B W O B \\
\mu & =\text { standard error term }
\end{aligned}
$$

To regress the equation, following hypothesis has been set up:

Null Hypothesis,

$$
H_{0}: B_{2}=B_{3}=B_{4}=0
$$

That is there is no relationship between explained as well as explanatory variables..

Alternative Hypothesis,

$$
H_{1}: B_{2}=B_{3}=B_{4} \neq 0
$$

There is a relationship between explained as well as explanatory variables.

\section{Methodology including detailed analysis plan and sample data collection instruments}

Research methodology includes Data source and Data collection procedures, Data analyzing procedures, Software Used in Data Analysis. For smooth and accurate study everyone has to follow some rules $\&$ regulations. The study inputs were collected from secondary sources. Data are collected from Dhaka stock exchange library, web site of selected banks, annual reports of the banks and over phone conversation.

\section{Sampling procedure and sample sizes: The following steps will be followed}

Step-1: Five commercial banks have to be selected.

Step-2: Annual reports of last ten years of selected banks will be collected.

Step-3: Websites of selected banks have to be shown.

Step-4: Over phone conversation with bank officers of selected banks will be conducted.

\section{Analysis plan: Descriptive and inferential analysis}

An eloquent analysis of data will be made using sound statistical tools like graphs, t-test, AVOVA, correlation, regression and percentage analysis will be used. Relative important issues will be identified and analysed. In order to meaningful analysis of the data, appropriate statistical tools will be used. It is noted that comparative analysis and previous study findings will be attempted. The study will follow the descriptive and inferential analysis.

\section{Limitation of the Report}

The main limitation of this report is that all the data are secondary data.

- The allotted time frame for the report was insufficient.

- Lack of published journal on the topic of loan classification.

- Lack of our expertise to conduct such econometric study as this is our first study in this field. The raw data were not tested through "Unit Root Test" for conducting the regression. 


\section{LITERATURE REVIEW}

Credit facilities are the main product and credit granting is very important decision of the banks because it determines the profitability of the banks. At present, banks are so much cognisant in the selection of customers to shun the bad loans or non-performing loans. Non-performing loans are the concerned issue from the last few decades. In the developing countries as well as developed countries are facing the alarming of increasing non-performing loans. The lending policy of the banks has a decisive pressure on non-performing loans. A default is not completely an unreasonable pronouncement. Rather a defaulter takes into account probabilistic evaluation of a variety of costs and benefits of his decision. Lazy banking significantly reflects on bank's investment portfolio and lending policy (Reddy \& Mohan (2003); Sinkey (1991) \& Dash (2010).

The immediate outcome of large amount of non-performing loans in the banking system is bank failure as well as economic slowdown. The reasons of non-performing loans are typically accredited to the lack of efficient monitoring and supervision on the part of banks, lack of efficient bankers, faults of legal infrastructure and lack of effective loan recovery systems (Adhikary, 2006).

At the practical level, there is no criterion to describe the non-performing loans. There are several disparities in the classification of loans, the scope, and contents. Non-performing loans have nonlinear negative effect on banks' lending behaviour (Hou, 2001)

Day by day the non-performing loans are increasing for lacking of risk management system of the banks which menaces the profitability of banks. This research presents the proposition that banking sector can avoid their non-performing loans by adopting methods suggested by the central bank of perspective country (Haneef\&Riaz, 2012).

It is alarming for the economy of our country that the non-performing loans are increasing in the both State Owned Commercial Banks (SOCBs) and other Financial Institutions (FIs), along with preservation of insufficient loan provisions, moderates the overall credit quality of Bangladesh. Poor enforcement of laws unfolding to resolve of non-performing loans, followed by inadequate debt recovery appraises on the part of the banks, has also exaggerated the financial depression. (Adhikary, 2007).

The loan performance is put into relation with macroeconomic indicators such as nominal interest rate, inflation rate, change in real GDP, economic growth, unemployment, and the change in terms of trade. One of the problems of such approach, taking macroeconomic variables as exogenous is that they are concurrently affected by a distress in the banking sector. (Foglia, 2008).

Non-performing loans are retreated on three sets of factors in terms of loan, banks size encouraged risk preference and the economic jolts. The pane regression models show the expressions of loan variables to be noteworthy. The estimated coefficient on amends in cost of loan because of anticipation of elevated interest rate is positive. On the contrary, possibility of maturity of loan, better loan culture and favourable economic conditions diminish the non-performing loans (Ranjan\& Dhal, 2003).

Non-performing loans are negatively related to GDP growth. Good loan helps to the development of the economy of any country. On the other hand, it is easily found that banks allege higher interest rates and lend excessively to the borrowers which indicating to the increasing of non-performing loans (Khemra, Saba \& Pasha, 1987).

The efficiency of the profitability of large commercial banks depends on the reducing of nonperforming loans. Non-performing loans and profitability are negatively related, it is not statistically significant (Fan and Shaffer 2004). Poor management of the banks results in bad quality of loans which indicates the increasing of non-performing loans (Calice 2012). 
An empirical result of econometric model based on a study on Guyana shows that GDP growth of any country is negatively related to the non-performing loans. Lower rate of non-performing loans indicates the improvement in the real economy of the country.

\section{THEORETICAL ANALYSIS (OVERVIEW OF}

\section{BANKS)}

\section{AB Bank Ltd}

Arab Bangladesh Bank Limited is the first private sector commercial bank in Bangladesh which was incorporated on 31st December 1981 as a name of $A B$ Bank Limited. It was the joint venture with Dubai Bank Limited, UAE. It was started the operation from April 12, 1982. Now it is called AB Bank Limited. It is one of the private commercial banks. At present, the Authorized Capital and the Equity of the Bank are BDT. 800.00 million And BDT. 1105.32 million Respectively. The Sponsor-Shareholders hold $50 \%$ of the Share Capital; the General Public Shareholders hold $49.30 \%$ and the rest $0.70 \%$ shares are held by the Government of the People's Republic of Bangladesh.

$A B$ Bank Limited offers all kinds of banking products and services such as Current and Savings accounts, FDR, fund transfer and utility bills receiving. All its services are classified as follows:

- International Banking

- Corporate Banking

- Retail Banking

- SME Banking

- Internet Banking

- NRB Banking

- Islamic Banking

\section{Prime Bank Ltd}

Prime Bank Limited was established on April 17, 1995 as a private commercial bank in Bangladesh. It started the banking activities on 17 April 1995. At present, it is one of the most pioneer private commercial banks in Bangladesh which pursues rules of Bangladesh Bank as well as international paradigm of Banking. The owners of the bank are presumed personalities in the business arena and their venture ranges from shipping to textile and finance to energy etc. There are offered several banking products and services by Prime bank Limited. Several kinds of diversified products and services are offered such as Corporate Banking, Retail Banking and Consumer Banking right from industry to agriculture, and real estate to software. In some cases, this bank works as a sponsor for arranging several tournaments.

All the products and services of Prime Bank limited are as follows:

- Internet Banking services

- Consumer banking

- Corporate banking

- Investment banking

- Islamic banking

\section{EXIM Bank Ltd}

EXIM Bank Limited (Export Import Bank Limited) was established under the rules and regulations of Bangladesh Bank on August, 1999 as a private commercial bank in Bangladesh. It started the banking activities in 1999 as a conventional bank. At present, it is operating the banking activities as shariah based bank or Islamic bank. It is one of the most pioneer private commercial banks in Bangladesh which pursues rules of international paradigm of Banking. The owners of the bank are presumed personalities in the business arena and their venture ranges from shipping to textile and finance to energy etc. There are offered several banking products and services by EXIM bank Limited. Several kinds of diversified products and services are offered such as Corporate Banking, Retail Banking and 
Consumer Banking right from industry to agriculture, and real estate to software. In some cases, this bank works as a sponsor for arranging several tournaments.

All the products and services of EXIM Bank limited are as follows:

- Islamic banking

- Remittance services

- Internet Banking services

- Consumer banking

- Corporate banking

- Investment banking

\section{The City Bank Limited}

The City Bank Limited was established in 1983 as a private commercial bank in Bangladesh. It started the banking activities in March 1983. At present, it is one of the most pioneer private commercial banks in Bangladesh which pursues rules of Bangladesh Bank as well as international paradigm of Banking. The owners of the bank are presumed personalities in the business arena and their venture ranges from shipping to textile and finance to energy etc. There are offered several banking products and services by The City bank Limited. Several kinds of diversified products and services are offered such as Corporate Banking, Retail Banking and Consumer Banking right from industry to agriculture, and real estate to software. In some cases, this bank works as a sponsor for arranging several tournaments. It was started with only BDT 3.4 core worth of capital which now reaches to BDT 330.77 core as capital. Now the bank has 87 online branches all over the country. It provides ATM services through 43 ATMs of its own and shares ATMs with other banks which more than 500 ATMs. This bank is the first bank in Bangladesh which issued dual currency credit card. The City Bank Limited is a main member of VISA international.

All the products and services of The City Bank limited are as follows:

- Internet Banking services

- Consumer banking

- Corporate banking

- Investment banking

- Islamic banking

\section{United Commercial Bank Ltd}

United Commercial Bank Limited was established in April 1983 as a private commercial bank in Bangladesh. It started the banking activities in 1983. At present, it is one of the most pioneer private commercial banks in Bangladesh which pursues rules of Bangladesh Bank as well as international paradigm of Banking. The owners of the bank are presumed personalities in the business arena and their venture ranges from shipping to textile and finance to energy etc. There are offered several banking products and services by United Commercial bank Limited. Several kinds of diversified products and services are offered such as Corporate Banking, Retail Banking and Consumer Banking right from industry to agriculture, and real estate to software. In some cases, this bank works as a sponsor for arranging several tournaments. United Commercial Bank Limited (UCBL) provides several commercial banking products and services in Bangladesh. It has a plan to open more branches over the next several years all over the country.

All the products and services of United Commercial Bank limited are as follows:

- Internet Banking services

- Consumer banking

- Corporate banking

- Investment banking

- Islamic banking 


\section{ANALYTICAL REVIEW}

\subsection{Ratio analysis}

Ratio analysis is very important for every business because ratio analysis helps to understand the business position, business strength and weakness. By knowing this information, management can take its necessary steps to organize their goal. Ratio analysis is pinpointing utensil that assists to recognize the problematic districts and chances within a company. The most important ratios of the financial institutions present insights banks.

\subsubsection{Ratio Analysis of $A B$ Bank Limited Profitability Ratios}

To analyse profitability, six distinct ratios are considered. These are:

- Return on Asset

- Return on Equity

- Return on Capital Employed

- Gross Profit Margin

- Net Profit Margin and

- Operating Profit Margin

Table 1: Ratio Analysis of AB Bank Limited

\begin{tabular}{|c|c|c|c|c|c|c|}
\hline Year & ROA & ROE & $\begin{array}{c}\text { Return on Capital } \\
\text { Employed }\end{array}$ & $\begin{array}{c}\text { Net Profit } \\
\text { Margin }\end{array}$ & $\begin{array}{c}\text { Net Profit } \\
\text { Margin }\end{array}$ & $\begin{array}{c}\text { Operating } \\
\text { Profit margin }\end{array}$ \\
\hline 2004 & $0.28 \%$ & $7.24 \%$ & $1.27 \%$ & $71.18 \%$ & $4.39 \%$ & $9.26 \%$ \\
\hline 2005 & $0.50 \%$ & $10.64 \%$ & $1.60 \%$ & $69.71 \%$ & $7.18 \%$ & $18.01 \%$ \\
\hline 2006 & $1.31 \%$ & $20.61 \%$ & $3.59 \%$ & $78.45 \%$ & $15.75 \%$ & $15.75 \%$ \\
\hline 2007 & $3.41 \%$ & $42.19 \%$ & $12.88 \%$ & $88.36 \%$ & $36.12 \%$ & $53.47 \%$ \\
\hline 2008 & $3.12 \%$ & $34.22 \%$ & $13.46 \%$ & $83.52 \%$ & $31.23 \%$ & $48.88 \%$ \\
\hline 2009 & $3.52 \%$ & $33.34 \%$ & $8.62 \%$ & $91.39 \%$ & $37.17 \%$ & $57.53 \%$ \\
\hline 2010 & $3.09 \%$ & $26.65 \%$ & $7.61 \%$ & $110.75 \%$ & $37.56 \%$ & $64.61 \%$ \\
\hline 2011 & $0.93 \%$ & $8.94 \%$ & $2.71 \%$ & $60.34 \%$ & $10.35 \%$ & $23.05 \%$ \\
\hline 2012 & $0.88 \%$ & $8.97 \%$ & $2.76 \%$ & $53.68 \%$ & $9.15 \%$ & $20.30 \%$ \\
\hline 2013 & $0.53 \%$ & $5.97 \%$ & $1.41 \%$ & $54.34 \%$ & $5.63 \%$ & $16.62 \%$ \\
\hline
\end{tabular}

\section{Return on Asset}

ROA of AB Bank Limited shows smaller fluctuations. In FY 2007 to FY 2010 the ROA was very closer. But in $\mathrm{FY} 2013$ it is $1.41 \%$ which shows that the bank is not able to use their total assets in efficient manner.

\section{Return on Equity}

The ROE of AB Bank Limited fluctuated largely in different years. In spite of very high ROE $(42.19 \%)$ in FY 2007, ROE has decreased gradually. The Graph shows a downward trend of ROE. It measures that shareholder's value are decreasing over the periods. 


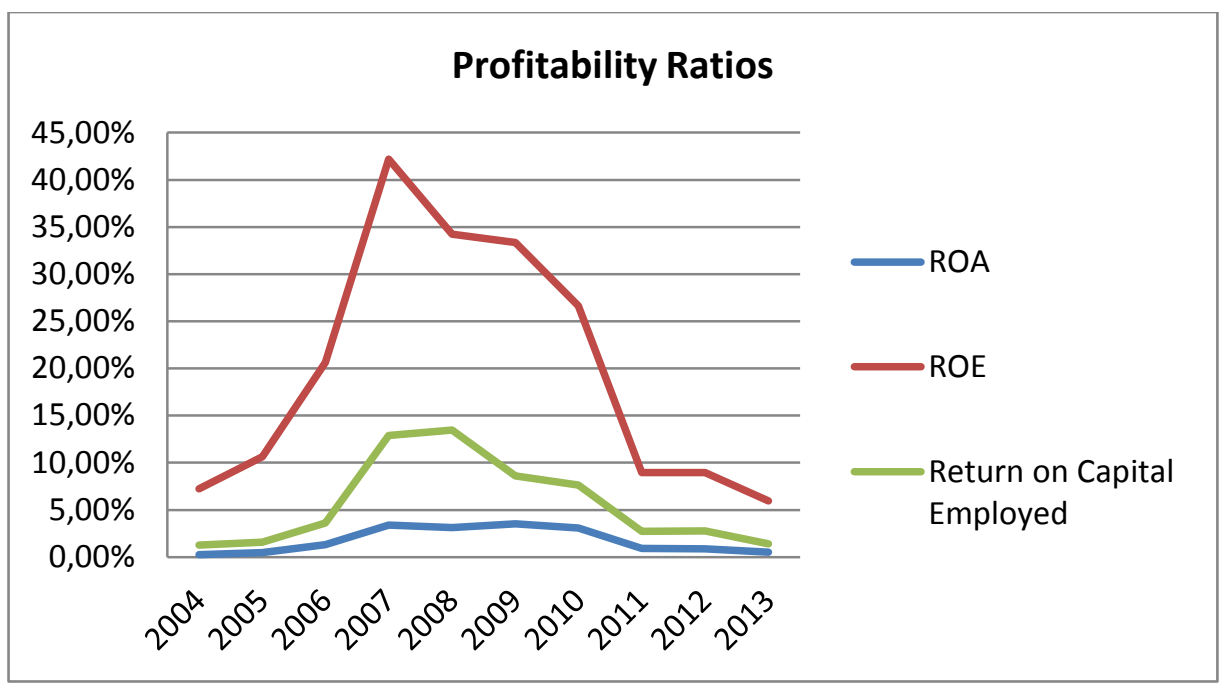

\section{Return on Capital Employed Ratio}

The return on capital employed ratio determines the return in respect of total amount of capital disbursed for loan and investment. This ratio is higher for FY 2007 and FY 2008. But in the FY 2012 and FY 2013 it has decreased.

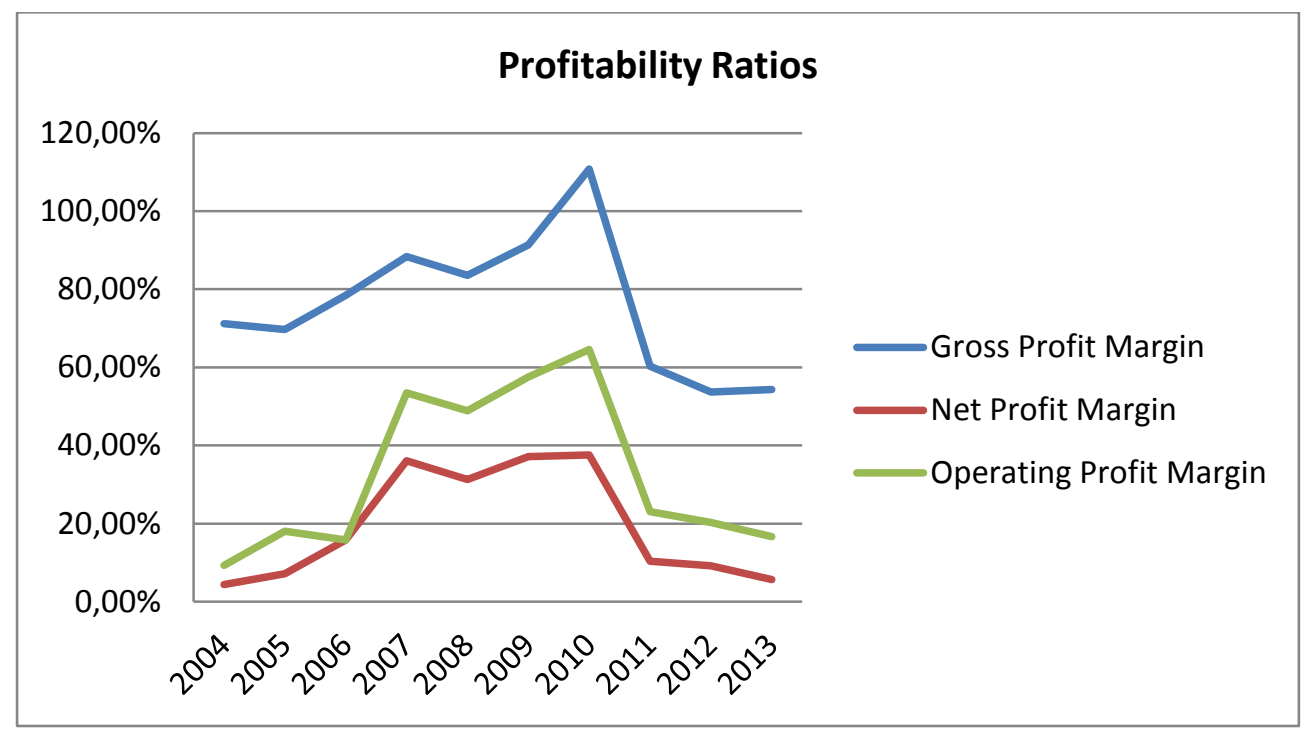

\section{Gross Profit Margin}

Gross Profit Margin illustrates the cost effectiveness of the entity. Gross Profit Margin was higher in FY 2010 but in FY 2013 it is smaller in respect of other periods. AB Bank is not performing well in case of minimizing their cost of fund.

\section{Operating Profit Margin}

It shows the profitability after meeting the cost of fund and operating expenses. The bank is obtaining lower operating profit margin. It means increasing operating expenses and cost of fund.

\section{Net Profit Margin}

The same thing like Gross Profit Margin and Operating Profit Margin is happening in case of Net Profit Margin. The bank is not performing in case of earning profit. 
Bijoy Chandra Das, Soma Rani Sutradhar

Econometric Study of Loan Classification of Commercial Banks in Bangladesh

\section{Liquidity Ratios}

To analyse liquidity of $A B$ Bank Limited, following ratios will be considered.

- Current Ratio

- Current Asset Ratio

- Loan Deposit Ratio

Table 2: Liquidity of AB Bank Limited

\begin{tabular}{llll}
\hline Year & Current Ratio & Current Asset Ratio & Loan Deposit Ratio \\
\hline $\mathbf{2 0 0 4}$ & $13.80 \%$ & $71.46 \%$ & $60.10 \%$ \\
$\mathbf{2 0 0 5}$ & $9.05 \%$ & $59.37 \%$ & $78.16 \%$ \\
$\mathbf{2 0 0 6}$ & $10.74 \%$ & $66.20 \%$ & $74.36 \%$ \\
$\mathbf{2 0 0 7}$ & $11.54 \%$ & $76.14 \%$ & $76.66 \%$ \\
$\mathbf{2 0 0 8}$ & $9.33 \%$ & $87.53 \%$ & $82.71 \%$ \\
$\mathbf{2 0 0 9}$ & $10.65 \%$ & $69.60 \%$ & $85.31 \%$ \\
$\mathbf{2 0 1 0}$ & $13.49 \%$ & $63.37 \%$ & $91.95 \%$ \\
$\mathbf{2 0 1 1}$ & $15.09 \%$ & $63.59 \%$ & $81.48 \%$ \\
$\mathbf{2 0 1 2}$ & $13.21 \%$ & $62.98 \%$ & $75.75 \%$ \\
$\mathbf{2 0 1 3}$ & $11.49 \%$ & $73.86 \%$ & $86.58 \%$ \\
\hline
\end{tabular}

\section{Current Ratio}

It shows the liquidity in terms of cash balance at hand and balance with other banks. The bank is maintaining a near consistent current ratio. The average current ratio is $11.84 \%$.

\section{Current Asset Ratio}

It measures the total cash and other liquid assets to total deposits. The bank is maintaining a good current asset ratio. The average current asset ratio is $69.41 \%$.

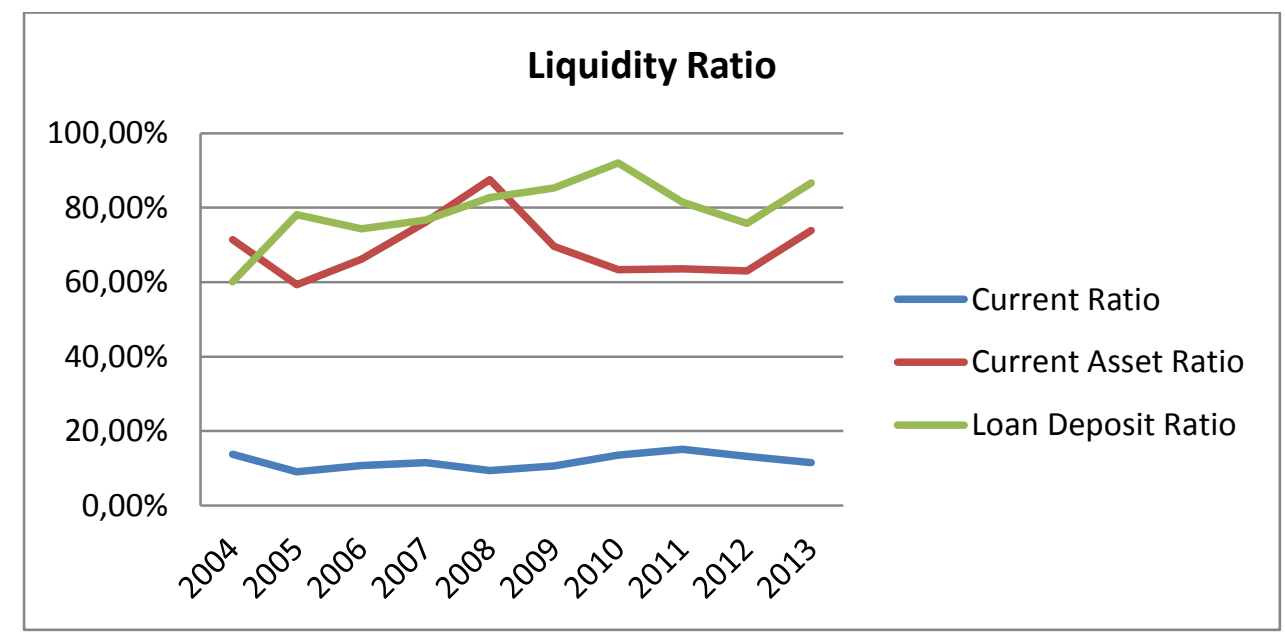

\section{Loan Deposit Ratio}

The bank has an increasing trend in loan deposit ratio. The bank is increasing its loan deposit ratio. The average loan deposit ratio is $79.31 \%$. Combining all the liquidity ratios together, it seems that the bank is performing well in maintaining liquidity. And the bank is able to meet the current liabilities.

\section{Risk and Solvency Ratio}

To comment on risk and solvency ratio, the following ratios are to be considered.

- Debt to equity ratio

- Debt to total asset ratio 
Bijoy Chandra Das, Soma Rani Sutradhar

Econometric Study of Loan Classification of Commercial Banks in Bangladesh

- $\quad$ Financial leverage ratio

Table 3: Risk and Solvency Ratio of AB Bank Limited

\begin{tabular}{llll}
\hline Year & Debt to Equity Ratio & $\begin{array}{l}\text { Debt to Total } \\
\text { Asset Ratio }\end{array}$ & Financial Leverage Ratio \\
\hline $\mathbf{2 0 0 4}$ & $294.03 \%$ & $96.18 \%$ & $189.44 \%$ \\
$\mathbf{2 0 0 5}$ & $418.24 \%$ & $95.38 \%$ & $185.30 \%$ \\
$\mathbf{2 0 0 6}$ & $394.60 \%$ & $94.62 \%$ & $133.54 \%$ \\
$\mathbf{2 0 0 7}$ & $143.67 \%$ & $92.90 \%$ & $118.00 \%$ \\
$\mathbf{2 0 0 8}$ & $71.20 \%$ & $92.00 \%$ & $119.38 \%$ \\
$\mathbf{2 0 0 9}$ & $211.19 \%$ & $90.57 \%$ & $111.48 \%$ \\
$\mathbf{2 0 1 0}$ & $185.77 \%$ & $89.55 \%$ & $116.55 \%$ \\
$\mathbf{2 0 1 1}$ & $151.15 \%$ & $90.29 \%$ & $145.81 \%$ \\
$\mathbf{2 0 1 2}$ & $136.49 \%$ & $90.78 \%$ & $136.76 \%$ \\
$\mathbf{2 0 1 3}$ & $210.39 \%$ & $91.86 \%$ & $177.23 \%$ \\
\hline
\end{tabular}

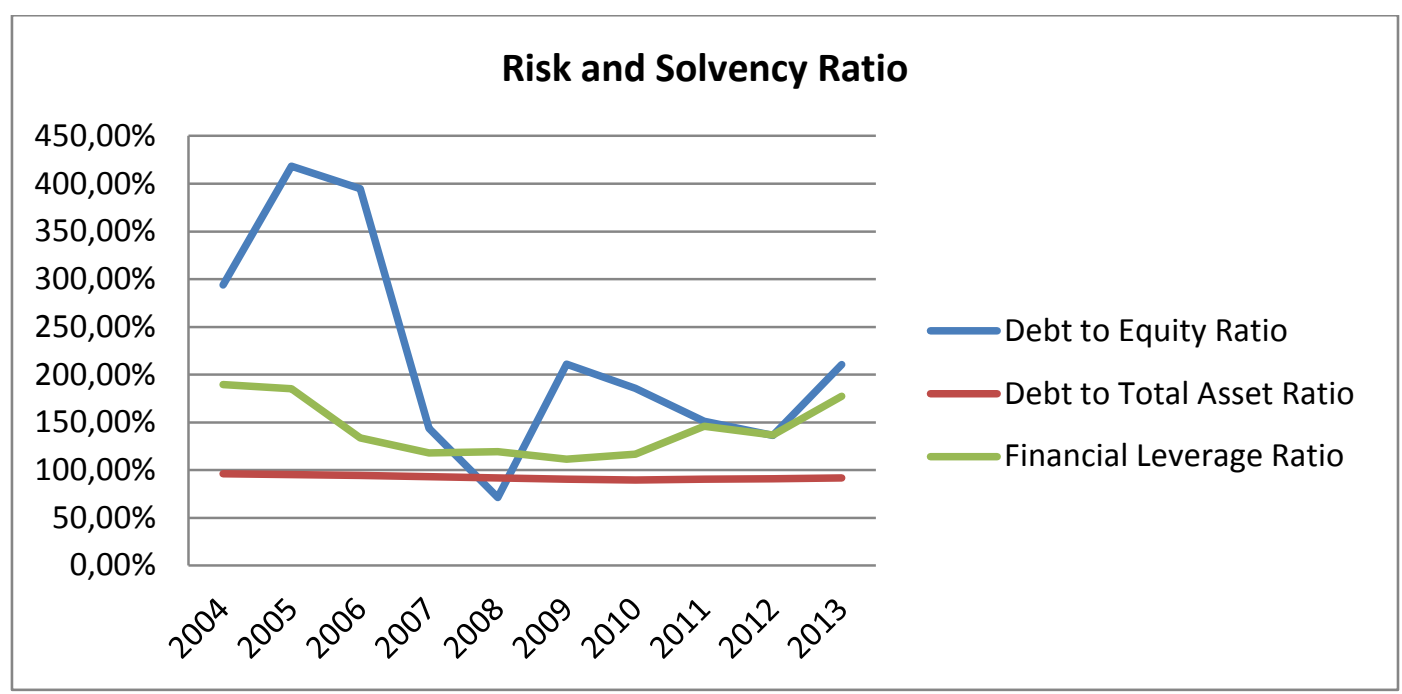

For analysing risk and solvency, it is seen that debt to equity ratio is fluctuated very highly for the periods. As the debt to equity ratio is decreasing in different years, riskiness of being default is low. The debt to total asset ratio is near constant. The fluctuation is very low. Financial leverage ratio shows the profitability due to use of debt. The bank is maintaining a reasonable leverage that is $143.35 \%$ in an average. Combining all together, the ratios show that the bank is able to minimize risk and solvent enough to meet the liabilities.

\section{Operating and activities ratios}

For operating and activities ratios, following ratios are to be considered.

- Net interest margin ratio

- Other operating income to asset ratio

- Non-Interest expenses to total asset ratio

- Fixed asset turnover 
Bijoy Chandra Das, Soma Rani Sutradhar

Econometric Study of Loan Classification of Commercial Banks in Bangladesh

Table 4: Operating and activities ratios of $A B$ Bank Limited

\begin{tabular}{llllll}
\hline Year & $\begin{array}{l}\text { Net interest } \\
\text { Margin } \\
\text { (NII/TA) }\end{array}$ & $\begin{array}{l}\text { Other } \\
\text { Income to Asset }\end{array}$ & $\begin{array}{l}\text { Operating } \\
\text { tnon-Interest } \\
\text { Expenses } \\
\text { Asset Ratio }\end{array}$ & $\begin{array}{l}\text { Noned } \\
\text { total }\end{array}$ & $\begin{array}{l}\text { Fixed } \\
\text { Turnover }\end{array}$ \\
\hline $\mathbf{2 0 0 4}$ & $1.57 \%$ & $4.49 \%$ & $3.38 \%$ & 7.42 \\
$\mathbf{2 0 0 5}$ & $2.09 \%$ & $4.77 \%$ & $2.49 \%$ & 6.12 \\
$\mathbf{2 0 0 6}$ & $1.28 \%$ & $5.52 \%$ & $4.04 \%$ & 2.94 \\
$\mathbf{2 0 0 7}$ & $2.26 \%$ & $7.33 \%$ & $2.09 \%$ & 2.21 \\
$\mathbf{2 0 0 8}$ & $2.42 \%$ & $7.32 \%$ & $2.21 \%$ & 3.01 \\
$\mathbf{2 0 0 9}$ & $2.72 \%$ & $7.73 \%$ & $2.31 \%$ & 3.71 \\
$\mathbf{2 0 1 0}$ & $2.62 \%$ & $8.21 \%$ & $2.63 \%$ & 2.51 \\
$\mathbf{2 0 1 1}$ & $1.57 \%$ & $5.06 \%$ & $2.24 \%$ & 3.33 \\
$\mathbf{2 0 1 2}$ & $1.80 \%$ & $4.85 \%$ & $2.34 \%$ & 3.72 \\
$\mathbf{2 0 1 3}$ & $1.82 \%$ & $4.69 \%$ & $2.15 \%$ & 4.30 \\
\hline
\end{tabular}
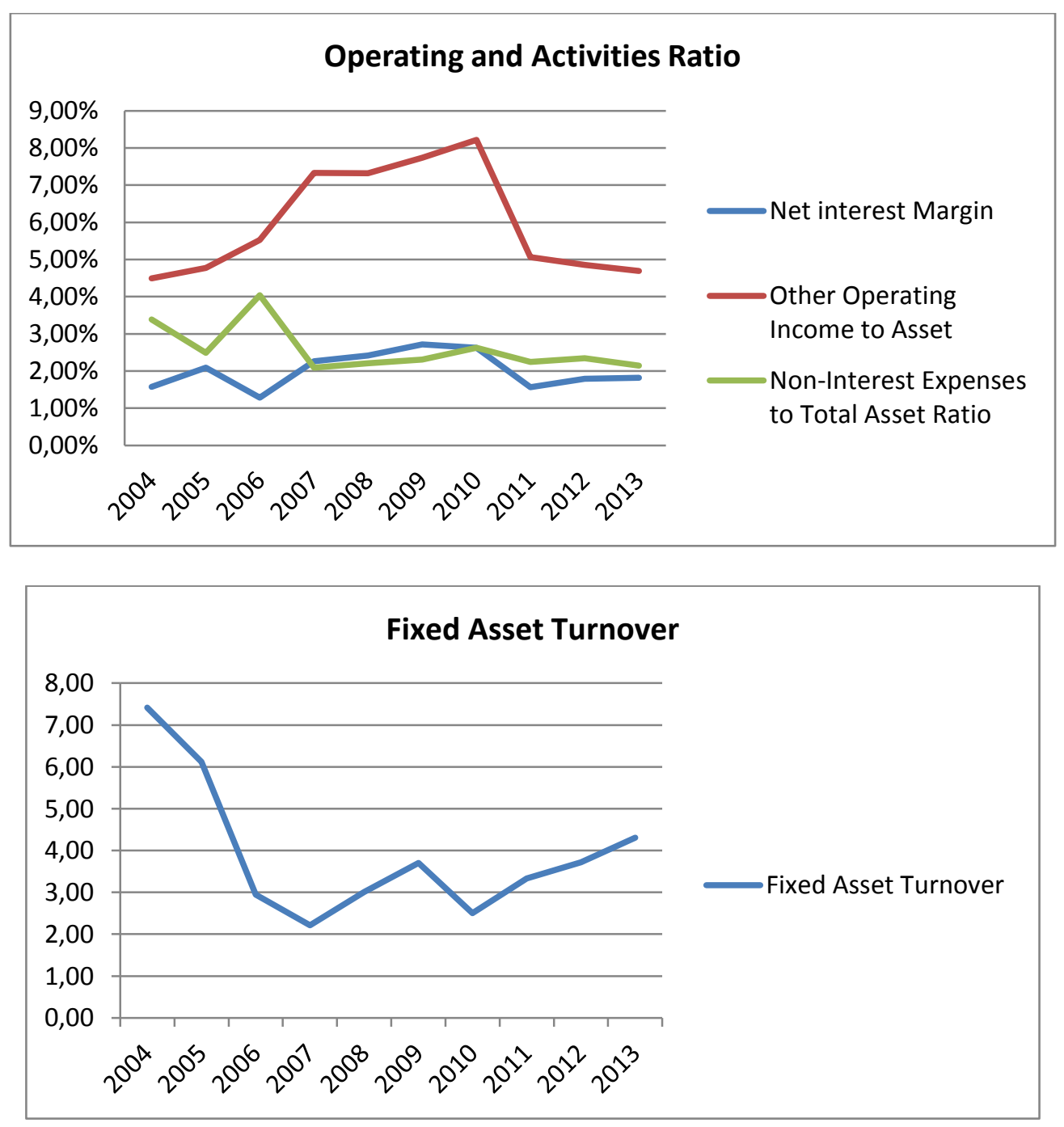

Net interest margin shows the net interest income to total assets. Higher net interest margin is good for the entity. In case of $A B$ Bank Limited this ratio is decreasing. Other operating income to total asset ratio shows the income to total asset arises from operation of the bank except interest income. 
If a bank is able to increase its operating income it is very good. Other non-interest expenses to total asset ratio is decreasing. The bank net fixed asset turnover was 7.42 times in FY 2004 but in 2013 the turnover is 4.30. This is showing their bad performance in operation. So, AB Bank Limited is not performing well.

\subsubsection{Ratio Analysis of Prime Bank Limited Profitability ratio}

Profitability ratio is one kind of ratio which is used to measure a business's capability to engender the earnings as contrast to its expenses and other costs acquired during a specific period of time.

To analyse profitability, six distinct ratios are considered. These are:

- Return on Asset

- Return on Equity

- Return on Capital Employed

- Gross Profit Margin

- Net Profit Margin and

- Operating Profit Margin

Table 5: Ratio Analysis of Prime Bank Limited

\begin{tabular}{llllllll}
\hline Year & ROA & ROE & $\begin{array}{l}\text { Return } \\
\text { Capital } \\
\text { Employed Ratio }\end{array}$ & $\begin{array}{l}\text { on } \\
\text { Gross } \\
\text { Profit } \\
\text { Margin }\end{array}$ & $\begin{array}{l}\text { Net } \\
\text { Margin }\end{array}$ & $\begin{array}{l}\text { Profit } \\
\text { Operating } \\
\text { Profit Margin }\end{array}$ \\
\hline $\mathbf{2 0 0 4}$ & $1.89 \%$ & $27.32 \%$ & $6.46 \%$ & $74.61 \%$ & $23.17 \%$ & $40.30 \%$ \\
$\mathbf{2 0 0 5}$ & $1.54 \%$ & $20.23 \%$ & $3.89 \%$ & $69.84 \%$ & $16.49 \%$ & $34.85 \%$ \\
$\mathbf{2 0 0 6}$ & $2.05 \%$ & $27.25 \%$ & $4.96 \%$ & $62.17 \%$ & $20.23 \%$ & $33.49 \%$ \\
$\mathbf{2 0 0 7}$ & $1.99 \%$ & $26.55 \%$ & $4.47 \%$ & $67.28 \%$ & $19.49 \%$ & $32.67 \%$ \\
$\mathbf{2 0 0 8}$ & $1.30 \%$ & $18.39 \%$ & $3.21 \%$ & $63.52 \%$ & $13.54 \%$ & $27.08 \%$ \\
$\mathbf{2 0 0 9}$ & $2.37 \%$ & $23.71 \%$ & $5.46 \%$ & $75.49 \%$ & $25.65 \%$ & $42.27 \%$ \\
$\mathbf{2 0 1 0}$ & $2.16 \%$ & $17.91 \%$ & $4.54 \%$ & $80.52 \%$ & $24.98 \%$ & $46.06 \%$ \\
$\mathbf{2 0 1 2}$ & $2.06 \%$ & $19.03 \%$ & $4.43 \%$ & $69.18 \%$ & $21.75 \%$ & $40.49 \%$ \\
$\mathbf{2 0 1 3}$ & $1.24 \%$ & $12.98 \%$ & $2.55 \%$ & $59.12 \%$ & $11.83 \%$ & $23.38 \%$ \\
\hline
\end{tabular}

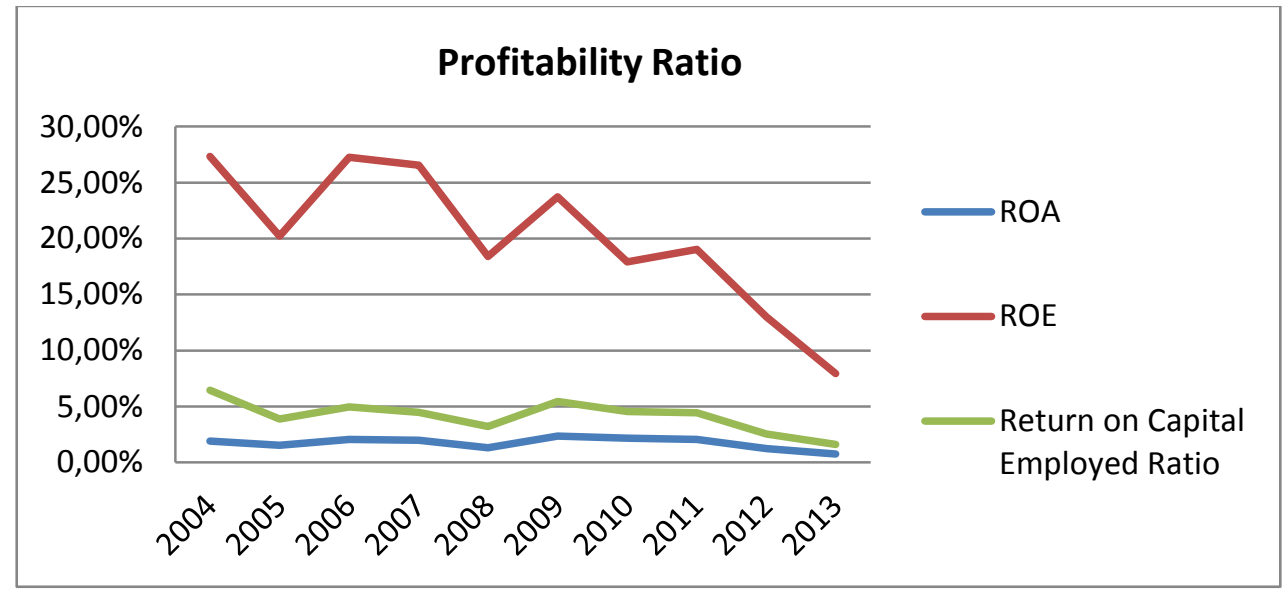

\section{Return on Asset}

Return on Asset ratio is used to test the capital exploitation that how much profit (before interest and income tax) is earned by a business on the total capital used to make that profit. ROA of Prime Bank Limited shows smaller fluctuations. In FY 2009 to FY 2011 the ROA was increased. But in FY 2013 it is 
decreased by $0.76 \%$ which shows that the bank is not able to use their total assets in efficient manner.

\section{Return on Equity}

Return on Equity determines the net income earned by exploited each dollar of total common equity. The ROE of Prime Bank Limited did not fluctuate largely in different years. The Graph shows a downward trend of ROE. It measures that shareholder's value are decreasing over the periods.

\section{Return on Capital Employed Ratio}

Return on Capital Employed ratio determines the return in respect of total capital disbursed for loans and investments. This ratio did not vary more in last 10 years. ROCE was higher than the bank's capital cost which indicates that the bank is employing its capital effectively and is generating shareholder's value.

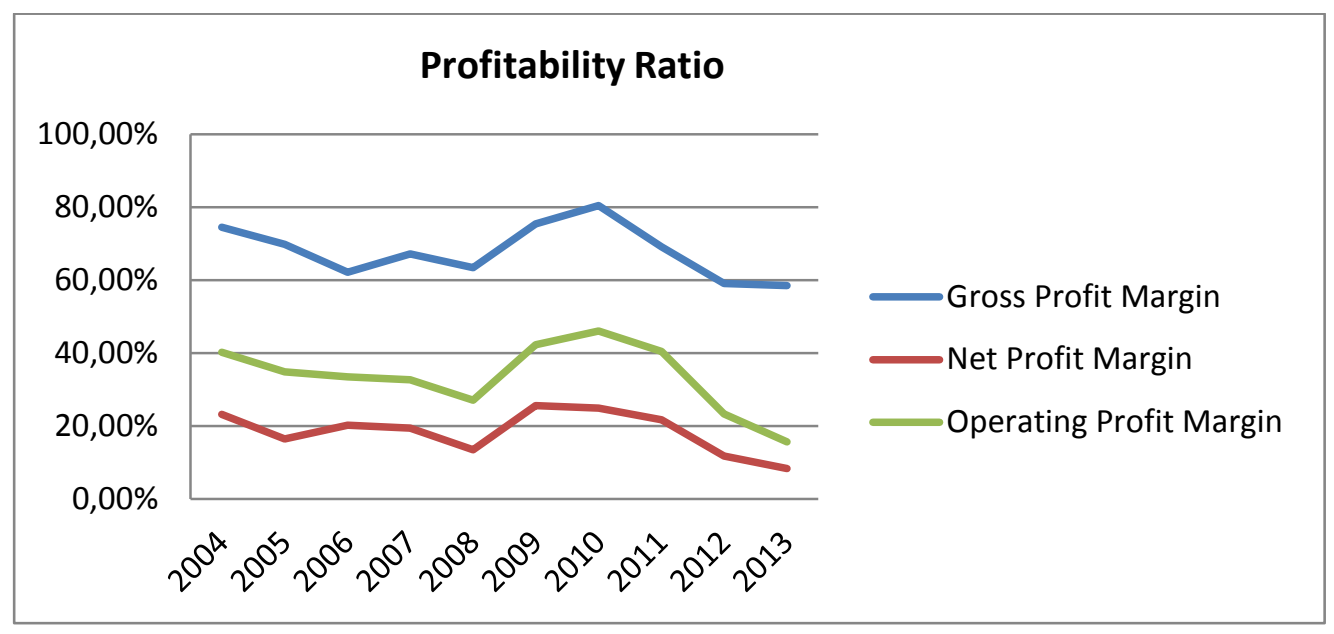

\section{Gross Profit Margin}

Gross profit margin shows the cost effectiveness of the entity. Gross Profit Margin was higher in FY 2010 but in FY 2013 it is smaller in respect of other periods. AB Bank is not performing well in case of minimizing their cost of fund.

\section{Operating Profit Margin}

Operating Profit Margin ratio is used to determine the bank's pricing tactic and operating effectiveness. The bank is obtaining higher operating profit margin which indicates lower operating expenses and cost of fund.

\section{Net Profit Margin}

Profit margin is a pointer of how competent a bank is and how well it manages its costs. Here the Net Profit Margin ratio has not significantly increased from years.

\section{Liquidity ratio}

Liquidity is the capability to congregate financial obligations as it befall due and is decisive to the sustainability of banking institutions.

To analyse liquidity of Prime Bank Limited, following ratios will be considered.

- Current Ratio

- Current Asset Ratio

- Loan Deposit Ratio 
Bijoy Chandra Das, Soma Rani Sutradhar

Econometric Study of Loan Classification of Commercial Banks in Bangladesh

Table 6: Liquidity of Prime Bank Limited

\begin{tabular}{llll}
\hline Year & Current Ratio & Current Asset Ratio & Loan Deposit Ratio \\
\hline $\mathbf{2 0 0 4}$ & $13.90 \%$ & $70.03 \%$ & $82.72 \%$ \\
$\mathbf{2 0 0 5}$ & $10.42 \%$ & $69.76 \%$ & $88.60 \%$ \\
$\mathbf{2 0 0 6}$ & $9.55 \%$ & $78.51 \%$ & $82.25 \%$ \\
$\mathbf{2 0 0 7}$ & $11.11 \%$ & $66.92 \%$ & $81.81 \%$ \\
$\mathbf{2 0 0 8}$ & $10.45 \%$ & $78.57 \%$ & $85.38 \%$ \\
$\mathbf{2 0 0 9}$ & $10.26 \%$ & $67.28 \%$ & $83.45 \%$ \\
$\mathbf{2 0 1 0}$ & $8.52 \%$ & $69.35 \%$ & $89.28 \%$ \\
$\mathbf{2 0 1 1}$ & $9.39 \%$ & $68.89 \%$ & $86.88 \%$ \\
$\mathbf{2 0 1 2}$ & $9.79 \%$ & $65.13 \%$ & $88.38 \%$ \\
$\mathbf{2 0 1 3}$ & $9.17 \%$ & $68.81 \%$ & $76.07 \%$ \\
\hline
\end{tabular}

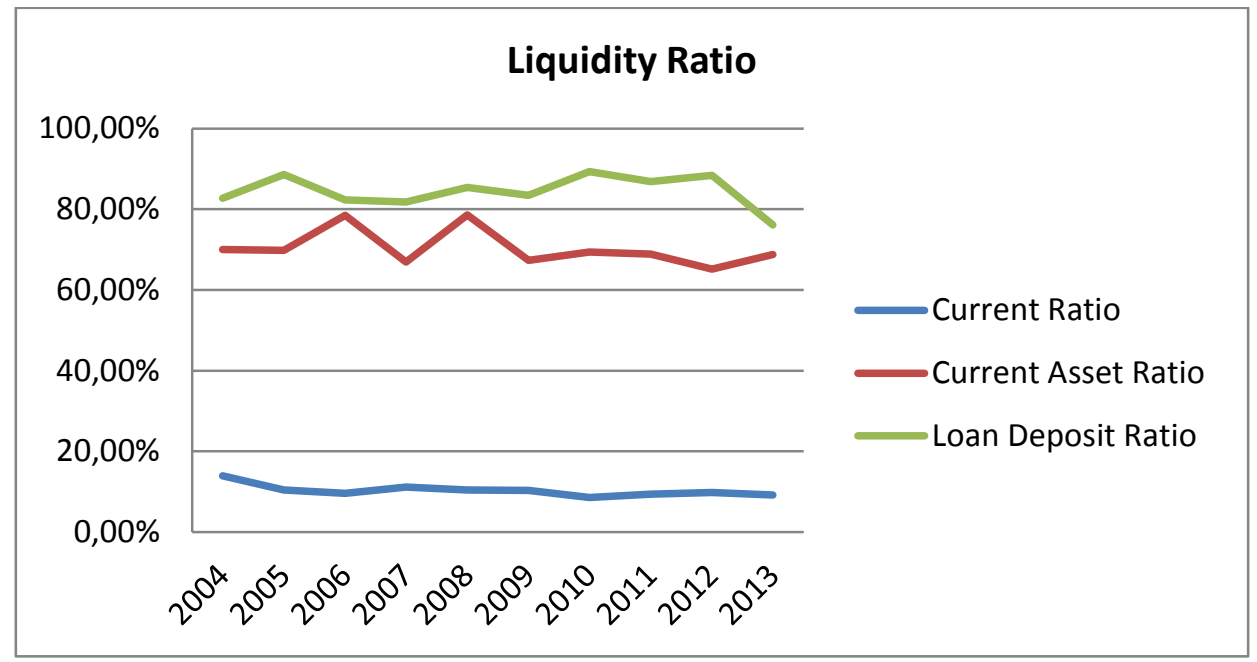

\section{Current Ratio}

Current ratio designates the degree to which current liabilities are covered by current assets in the near future. The average current ratio is $13.27 \%$.

\section{Current Asset Ratio}

It measures the total cash and other liquid assets to total deposits. The bank is maintaining a good current asset ratio. The average current asset ratio is $68.82 \%$.

\section{Loan Deposit Ratio}

When total loan is divided by total deposit amounts then we get loan deposit ratio. It is assessed in statistic for evaluating the bank's liquidity position. Here the loan deposit ratio fluctuated very merely from the year 2004 to 2013. It is easily realized that the bank depends on its own funds to create credits to borrowers without any outside borrowings. Combining all the liquidity ratios together, it seems that the bank is performing well in maintaining liquidity. And the bank is able to meet the current liabilities.

\section{Risk and solvency ratio}

Risk and Solvency ratios are debt to equity ratio, debt to total asset ratio and financial leverage ratio. The ratios are to be considered:

- Debt to equity ratio

- Debt to total asset ratio

- Financial leverage ratio 
Bijoy Chandra Das, Soma Rani Sutradhar

Econometric Study of Loan Classification of Commercial Banks in Bangladesh

Table 7: Risk and solvency ratio of Prime Bank Limited

\begin{tabular}{llll}
\hline Year & Debt to Equity Ratio & Debt to Total Asset Ratio & Financial Leverage Ratio \\
\hline $\mathbf{2 0 0 4}$ & $248.28 \%$ & $93.08 \%$ & $107.70 \%$ \\
$\mathbf{2 0 0 5}$ & $358.59 \%$ & $93.23 \%$ & $126.61 \%$ \\
$\mathbf{2 0 0 6}$ & $398.31 \%$ & $93.66 \%$ & $122.40 \%$ \\
$\mathbf{2 0 0 7}$ & $429.40 \%$ & $93.38 \%$ & $138.81 \%$ \\
$\mathbf{2 0 0 8}$ & $409.06 \%$ & $93.94 \%$ & $156.16 \%$ \\
$\mathbf{2 0 0 9}$ & $282.74 \%$ & $90.59 \%$ & $115.24 \%$ \\
$\mathbf{2 0 1 0}$ & $248.75 \%$ & $89.03 \%$ & $109.75 \%$ \\
$\mathbf{2 0 1 1}$ & $277.14 \%$ & $90.45 \%$ & $109.77 \%$ \\
$\mathbf{2 0 1 2}$ & $344.90 \%$ & $91.22 \%$ & $160.28 \%$ \\
$\mathbf{2 0 1 3}$ & $331.86 \%$ & $90.56 \%$ & $216.93 \%$ \\
\hline
\end{tabular}

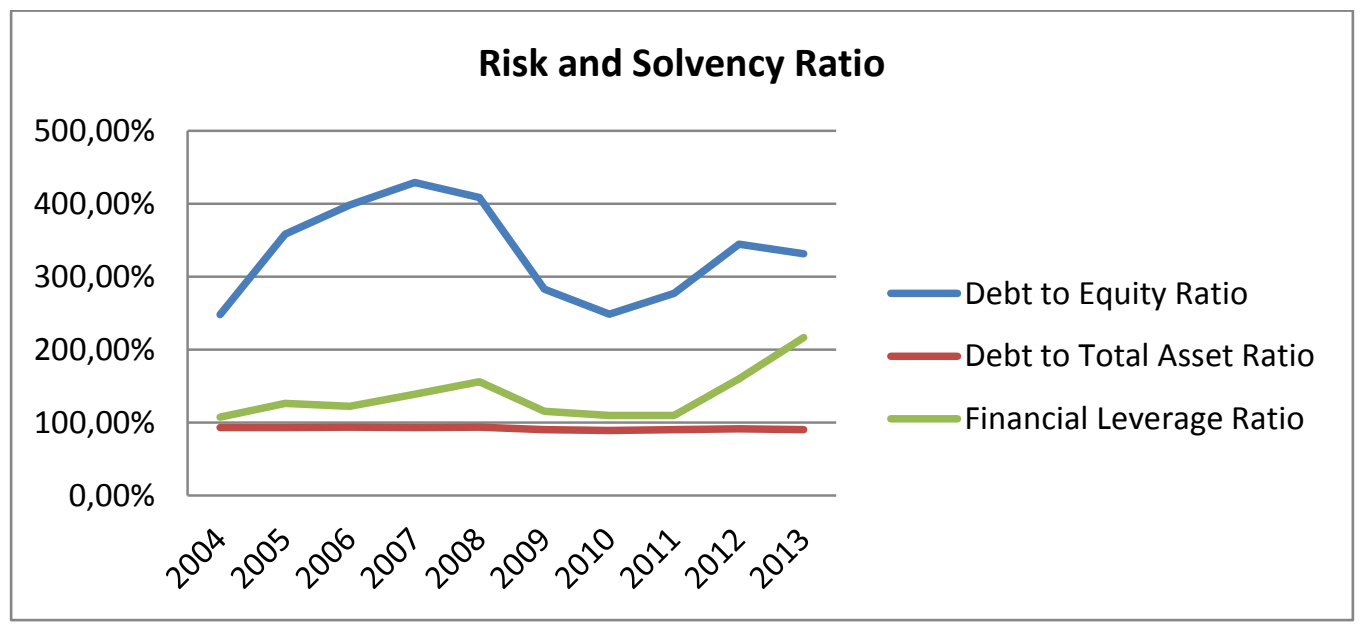

For analysing risk and solvency, it is seen that debt to equity ratio is fluctuated very highly for the periods. The debt to equity ratio was increased from FY 2004 to FY 2008 but from FY 2009 it tended to fall which showed that riskiness of being default was low. The debt to total asset ratio was almost constant for the last 10 years. . Financial leverage ratio shows the profitability due to use of debt. The bank is maintaining a reasonable leverage that is $136.35 \%$ in an average. Combining all together, the ratios show that the bank is able to minimize risk and solvent enough to meet the liabilities.

\section{Operating and activities ratio}

Operating ratio is calculated by operating expenses to net sales and activity ratios are those that determine the bank's capability to renovate different accounts within the balance sheets into cash or sales.

For operating and activities ratios, following ratios are to be considered.

- Net interest margin ratio

- Other operating income to asset ratio

- Non-Interest expenses to total asset ratio

- Fixed asset turnover 
Bijoy Chandra Das, Soma Rani Sutradhar

Econometric Study of Loan Classification of Commercial Banks in Bangladesh

Table 8: Operating and activities ratio of Prime Bank Limited

\begin{tabular}{llllll}
\hline Year & $\begin{array}{l}\text { Net interest } \\
\text { Margin }\end{array}$ & $\begin{array}{l}\text { Other } \\
\text { Income to Asset }\end{array}$ & $\begin{array}{l}\text { Operating } \\
\text { Notal Asset Ratio }\end{array}$ & $\begin{array}{c}\text { to } \\
\text { Tosset } \\
\text { Turnover }\end{array}$ \\
\hline $\mathbf{2 0 0 4}$ & $3.17 \%$ & $6.09 \%$ & $2.55 \%$ & 8.21 \\
$\mathbf{2 0 0 5}$ & $2.83 \%$ & $5.80 \%$ & $2.13 \%$ & 9.26 \\
$\mathbf{2 0 0 6}$ & $2.46 \%$ & $5.31 \%$ & $1.81 \%$ & 12.62 \\
$\mathbf{2 0 0 7}$ & $2.40 \%$ & $6.07 \%$ & $1.98 \%$ & 10.87 \\
$\mathbf{2 0 0 8}$ & $1.78 \%$ & $5.23 \%$ & $1.75 \%$ & 6.62 \\
$\mathbf{2 0 0 9}$ & $1.95 \%$ & $6.57 \%$ & $2.33 \%$ & 6.90 \\
$\mathbf{2 0 1 0}$ & $2.77 \%$ & $6.34 \%$ & $2.36 \%$ & 7.11 \\
$\mathbf{2 0 1 1}$ & $2.03 \%$ & $5.78 \%$ & $2.07 \%$ & 4.20 \\
$\mathbf{2 0 1 2}$ & $2.28 \%$ & $5.70 \%$ & $2.09 \%$ & 5.23 \\
$\mathbf{2 0 1 3}$ & $1.78 \%$ & $5.28 \%$ & $2.22 \%$ & 3.44 \\
\hline
\end{tabular}

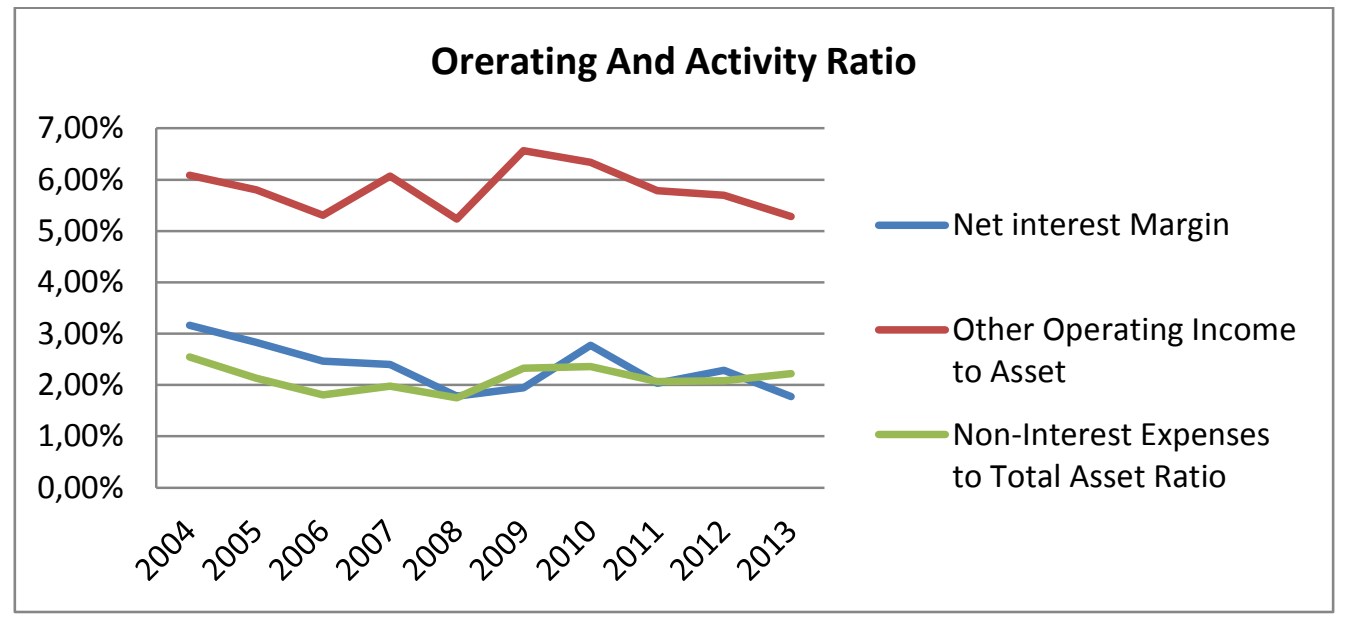

In prime Bank Limited, from year 2004 to 2013 net interest margin ratio represents a positive sign. Here the net interest margin increased from year to year. It shows how flourishing a bank's investment decisions are evaluated to its debt positions. Here the operating income to total asset ratio from year 2004 to2013 shows a merely result. The earnings of Prime Bank Limited in proportion to its assets are low which results that the less effectively the bank is using its asset.

Other non-interest expenses to total asset ratio was not fluctuated too much for last 10 years. The bank net fixed asset turnover was decreasing from year to year which is alarming for the bank. This is showing their bad performance in operation.

\subsubsection{Ratio Analysis of EXIM Bank Limited Profitability Ratios}

To analyse profitability, six distinct ratios are considered which are:

- Return on Asset

- Return on Equity

- Return on Capital Employed

- Gross Profit Margin

- Net Profit Margin and

- Operating Profit Margin 
Bijoy Chandra Das, Soma Rani Sutradhar

Econometric Study of Loan Classification of Commercial Banks in Bangladesh

Table 9: Ratio Analysis of EXIM Bank Limited

\begin{tabular}{llllllll}
\hline year & ROA & ROE & $\begin{array}{l}\text { Return on Capital } \\
\text { Employed }\end{array}$ & $\begin{array}{l}\text { Gross } \\
\text { Margin }\end{array}$ & $\begin{array}{l}\text { Profit } \\
\text { Margin }\end{array}$ & $\begin{array}{l}\text { Profit } \\
\text { Operating } \\
\text { Profit Margin }\end{array}$ \\
\hline $\mathbf{2 0 0 4}$ & $1.57 \%$ & $27.27 \%$ & $3.82 \%$ & $66.5 \%$ & $21.0 \%$ & $35.5 \%$ \\
$\mathbf{2 0 0 5}$ & $1.91 \%$ & $29.04 \%$ & $4.76 \%$ & $65.5 \%$ & $22.6 \%$ & $43.2 \%$ \\
$\mathbf{2 0 0 6}$ & $1.75 \%$ & $21.23 \%$ & $4.04 \%$ & $52.9 \%$ & $17.3 \%$ & $31.5 \%$ \\
$\mathbf{2 0 0 7}$ & $2.00 \%$ & $23.03 \%$ & $4.35 \%$ & $57.1 \%$ & $18.8 \%$ & $32.7 \%$ \\
$\mathbf{2 0 0 8}$ & $1.83 \%$ & $21.98 \%$ & $4.77 \%$ & $54.0 \%$ & $16.7 \%$ & $30.3 \%$ \\
$\mathbf{2 0 0 9}$ & $2.19 \%$ & $25.22 \%$ & $6.33 \%$ & $54.5 \%$ & $20.8 \%$ & $34.4 \%$ \\
$\mathbf{2 0 1 0}$ & $3.49 \%$ & $27.86 \%$ & $10.98 \%$ & $80.2 \%$ & $36.2 \%$ & $55.3 \%$ \\
$\mathbf{2 0 1 1}$ & $1.65 \%$ & $13.87 \%$ & $5.91 \%$ & $49.1 \%$ & $15.3 \%$ & $26.5 \%$ \\
$\mathbf{2 0 1 2}$ & $1.45 \%$ & $12.97 \%$ & $5.59 \%$ & $46.7 \%$ & $12.5 \%$ & $21.3 \%$ \\
$\mathbf{2 0 1 3}$ & $1.06 \%$ & $9.28 \%$ & $4.22 \%$ & $39.9 \%$ & $9.4 \%$ & $15.9 \%$ \\
\hline
\end{tabular}

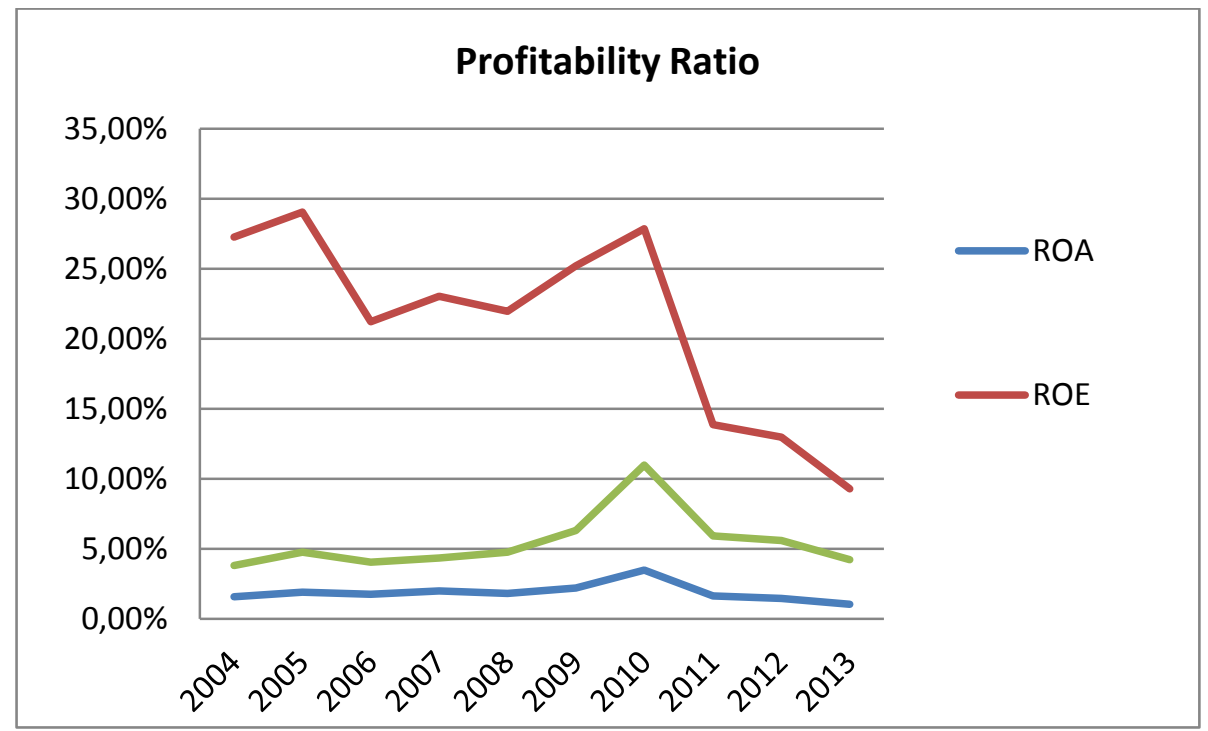

\section{Return on Asset}

ROA of EXIM Bank Limited indicates a little fluctuation over the years. From the FY 2004 to FY 2008 the ROA was very closer. But in FY 2013 it is $1.06 \%$ which indicates that the bank is not able to use their total assets in an efficient manner.

\section{Return on Equity}

The ROE of EXIM Bank Limited is largely fluctuated from the year 2009 to 2011 . Though the ROE was increased in 2010, it has decreased gradually from the year. The Graph shows a downward trend of ROE from 2010. It measures that shareholder's value are decreasing over the periods or they will get less benefit in future.

\section{Return on Capital Employed Ratio}

The Return on Capital Employed ratio determines the return in respect of total amount of capital disbursed for loan and investment. This ratio shows a large fluctuation form the year 2003 to 2013 and it is in decreasing trend. It reveals that the return on the used capital is getting decreased day by day. 


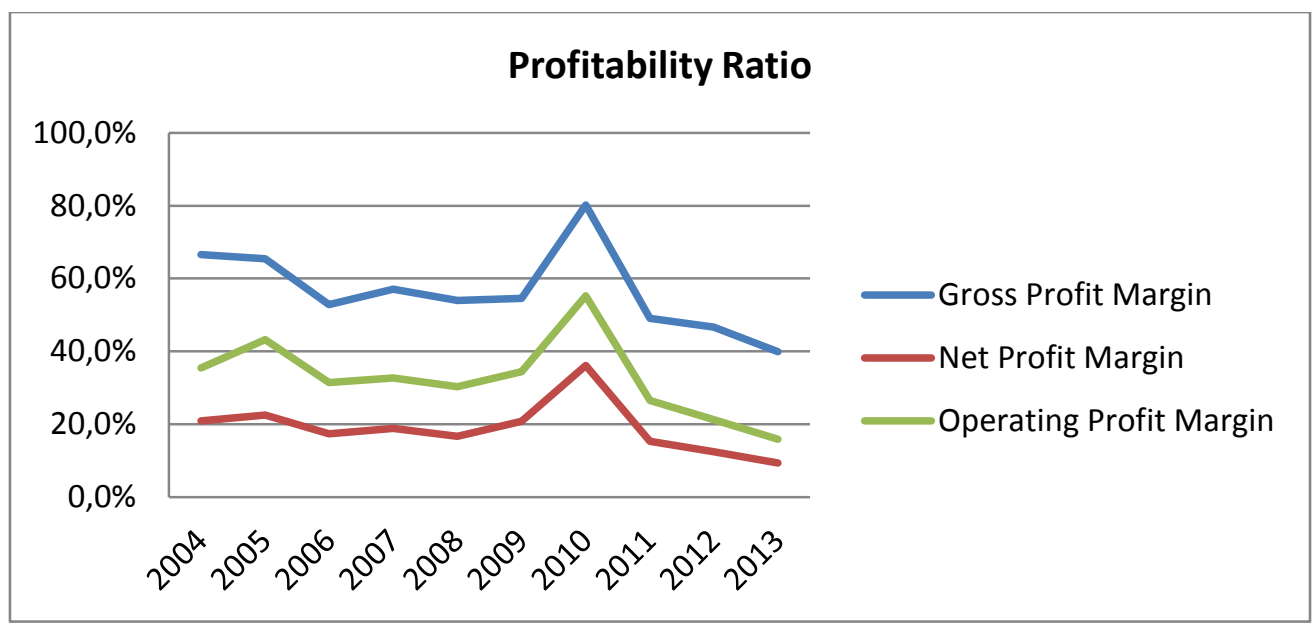

\section{Gross Profit Margin}

Gross profit margin shows the cost effectiveness of the entity. Gross Profit Margin was higher in FY 2010 but in FY 2013 it gets decreased in respect of other periods. EXIM Bank is not performing well as its gross profit is in decreasing trend from the year after 2010.

\section{Operating Profit Margin}

It shows the profitability after meeting the cost of fund and operating expenses. The bank is obtaining lower operating profit margin. It means increasing operating expenses and cost of fund. The trend of this ratio indicates that the risk of the banking sector is getting increased day by day.

\section{Net Profit Margin}

The condition of Net Profit Margin is as well as the Gross Profit Margin and the operating profit margin. Under this condition it can be assume that the bank is not performing well. Beside this, it will not be able to ensure good profit to its shareholders in future.

\section{Liquidity Ratios}

To analyse liquidity of EXIM Bank Limited, following ratios will be considered.

- Current Ratio

- Current Asset Ratio

- Loan Deposit Ratio

Table 10: Liquidity Ratios of EXIM Bank Limited

\begin{tabular}{llll}
\hline Year & Current Ratio & Current Asset Ratio & Loan Deposit Ratio \\
\hline $\mathbf{2 0 0 4}$ & $12.69 \%$ & $72.16 \%$ & $8.09 \%$ \\
$\mathbf{2 0 0 5}$ & $16.37 \%$ & $72.04 \%$ & $5.77 \%$ \\
$\mathbf{2 0 0 6}$ & $13.53 \%$ & $67.67 \%$ & $6.37 \%$ \\
$\mathbf{2 0 0 7}$ & $14.22 \%$ & $64.78 \%$ & $5.92 \%$ \\
$\mathbf{2 0 0 8}$ & $14.92 \%$ & $65.52 \%$ & $4.92 \%$ \\
$\mathbf{2 0 0 9}$ & $14.55 \%$ & $66.02 \%$ & $2.97 \%$ \\
$\mathbf{2 0 1 0}$ & $12.07 \%$ & $72.59 \%$ & $5.89 \%$ \\
$\mathbf{2 0 1 1}$ & $18.71 \%$ & $73.95 \%$ & $7.09 \%$ \\
$\mathbf{2 0 1 2}$ & $24.97 \%$ & $79.32 \%$ & $8.06 \%$ \\
\hline $\mathbf{2 0 1 3}$ & $20.51 \%$ & $79.71 \%$ & $7.49 \%$ \\
\hline
\end{tabular}




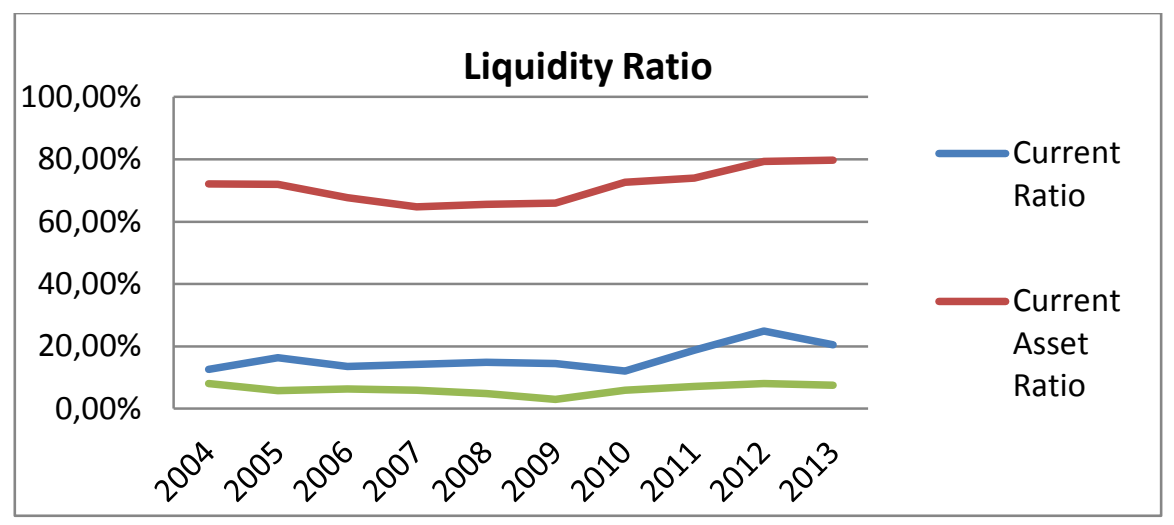

\section{Current Ratio}

It shows the liquidity in terms of cash balance at hand and balance with other banks. Bank's trend of the current ratio is upward sloping. The average current ratio is $16.25 \%$. As the bank has the current ratio 20.51 in 2013, it indicates that the bank is able to meet its current demand at a very short time.

\section{Current Asset Ratio}

It measures the total cash and other liquid assets to total deposits. The bank is maintaining a good current asset ratio. The average current asset ratio is $71.38 \%$. It indicates that the bank is intended to maintain on an average $71.38 \%$ liquid asset to congregate its short term need.

\section{Loan Deposit Ratio}

Loan to deposit ratio of the EXIM bank is increasing from 2009 to 2013 but the rate of increase is very low. The average loan to deposit ratio is $6.26 \%$. The overall condition of the loan to deposit ratio is low for this bank because the bank mainly deals with the export import business.

So the bank liquidity ratio indicates that the bank is performing well in case of liquidity and the bank is now able to meet the current liabilities.

\section{Risk and Solvency Ratio}

To comment on Risk and Solvency ratio, the following ratios are to be considered.

- $\quad$ Debt to equity ratio

- Debt to total asset ratio

- Financial leverage ratio

Table 11: Risk and Solvency Ratio of EXIM Bank Limited

\begin{tabular}{|c|c|c|c|c|}
\hline Year & Debt to Equity Ratio & $\begin{array}{l}\text { Debt to Total Asset } \\
\text { Ratio }\end{array}$ & $\begin{array}{l}\text { Financial } \\
\text { Ratio }\end{array}$ & Leverage \\
\hline 2004 & $107.36 \%$ & $94.25 \%$ & $129.45 \%$ & \\
\hline 2005 & $78.59 \%$ & $94.33 \%$ & $110.58 \%$ & \\
\hline 2006 & $64.44 \%$ & $92.55 \%$ & $114.94 \%$ & \\
\hline 2007 & $55.79 \%$ & $92.15 \%$ & $117.88 \%$ & \\
\hline 2008 & $45.20 \%$ & $92.71 \%$ & $126.58 \%$ & \\
\hline 2009 & $30.15 \%$ & $92.21 \%$ & $113.55 \%$ & \\
\hline 2010 & $32.29 \%$ & $88.97 \%$ & $111.02 \%$ & \\
\hline 2011 & $27.91 \%$ & $88.85 \%$ & $113.83 \%$ & \\
\hline 2012 & $27.74 \%$ & $90.04 \%$ & $144.62 \%$ & \\
\hline 2013 & $5.85 \%$ & $89.45 \%$ & $151.75 \%$ & \\
\hline
\end{tabular}




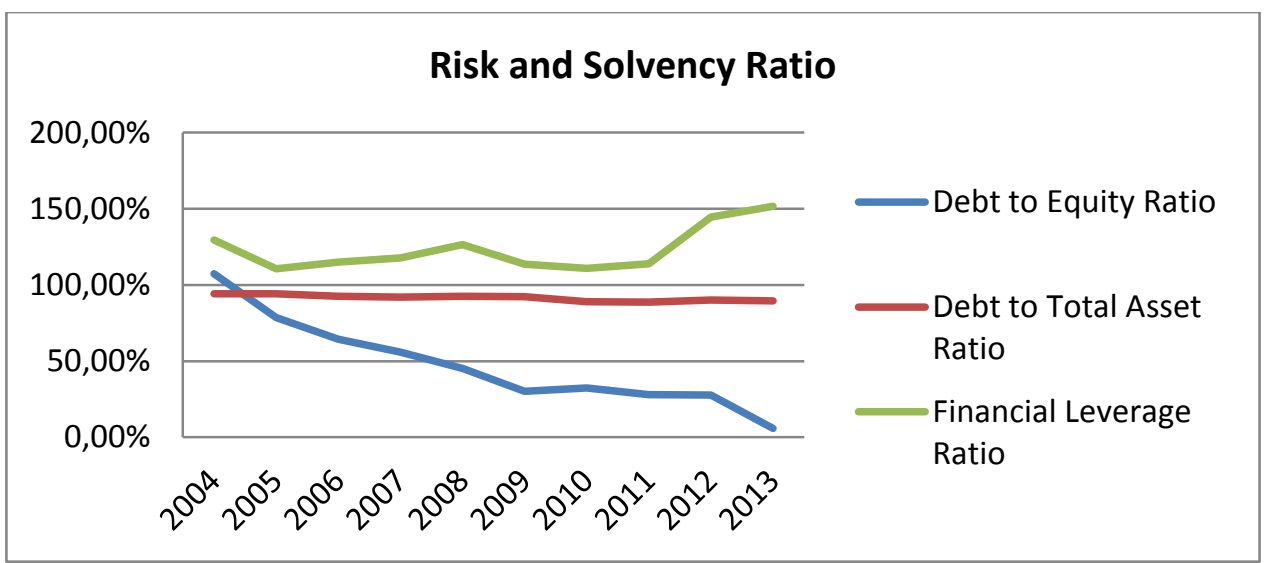

For analysing risk and solvency, we have to calculate debt equity, debt to total asset and financial leverage ratio. The graph shows that the bank is moving on the equity financing rather than debt financing as the debt to equity ratio is decreasing in different years. This shows that the bank is going on riskless financing. The debt to total asset ratio is near constant. The fluctuation is very low. Financial leverage ratio shows the profitability due to use of debt. The bank is maintaining a reasonable leverage that is $123.42 \%$ in an average. The overall condition of the financial leverage ratio is upward sloping in the last 3 years. Combining all together, the ratios show that the bank is able to minimize risk and solvent enough to meet the liabilities.

\section{Operating and activities ratios}

For operating and activities ratios, following ratios are to be considered.

- Net interest margin ratio

- Other operating income to asset ratio

- Non-Interest expenses to total asset ratio

- $\quad$ Fixed asset turnover

Table 12: Operating and activities ratios of EXIM Bank Limited

\begin{tabular}{|c|c|c|c|c|c|c|}
\hline Year & $\begin{array}{l}\text { Net interest } \\
\text { Margin }\end{array}$ & $\begin{array}{l}\text { Other Operating } \\
\text { Income to Asset }\end{array}$ & $\begin{array}{l}\text { Non-Interest } \\
\text { Expenses to } \\
\text { Asset Ratio }\end{array}$ & Total & $\begin{array}{l}\text { Fixed } \\
\text { Turnover }\end{array}$ & Asset \\
\hline 2004 & $1.62 \%$ & $4.97 \%$ & $1.54 \%$ & & 12.07 & \\
\hline 2005 & $1.90 \%$ & $4.78 \%$ & $1.29 \%$ & & 14.74 & \\
\hline 2006 & $2.04 \%$ & $4.82 \%$ & $1.52 \%$ & & 21.34 & \\
\hline 2007 & $2.63 \%$ & $5.48 \%$ & $1.77 \%$ & & 24.63 & \\
\hline 2008 & $2.58 \%$ & $5.19 \%$ & $1.51 \%$ & & 22.40 & \\
\hline 2009 & $2.56 \%$ & $5.15 \%$ & $1.46 \%$ & & 21.33 & \\
\hline 2010 & $3.17 \%$ & $6.81 \%$ & $1.60 \%$ & & 20.71 & \\
\hline 2011 & $2.90 \%$ & $4.96 \%$ & $1.92 \%$ & & 28.04 & \\
\hline 2012 & $3.01 \%$ & $4.84 \%$ & $1.65 \%$ & & 39.96 & \\
\hline 2013 & $2.54 \%$ & $4.17 \%$ & $1.65 \%$ & & 6.41 & \\
\hline
\end{tabular}



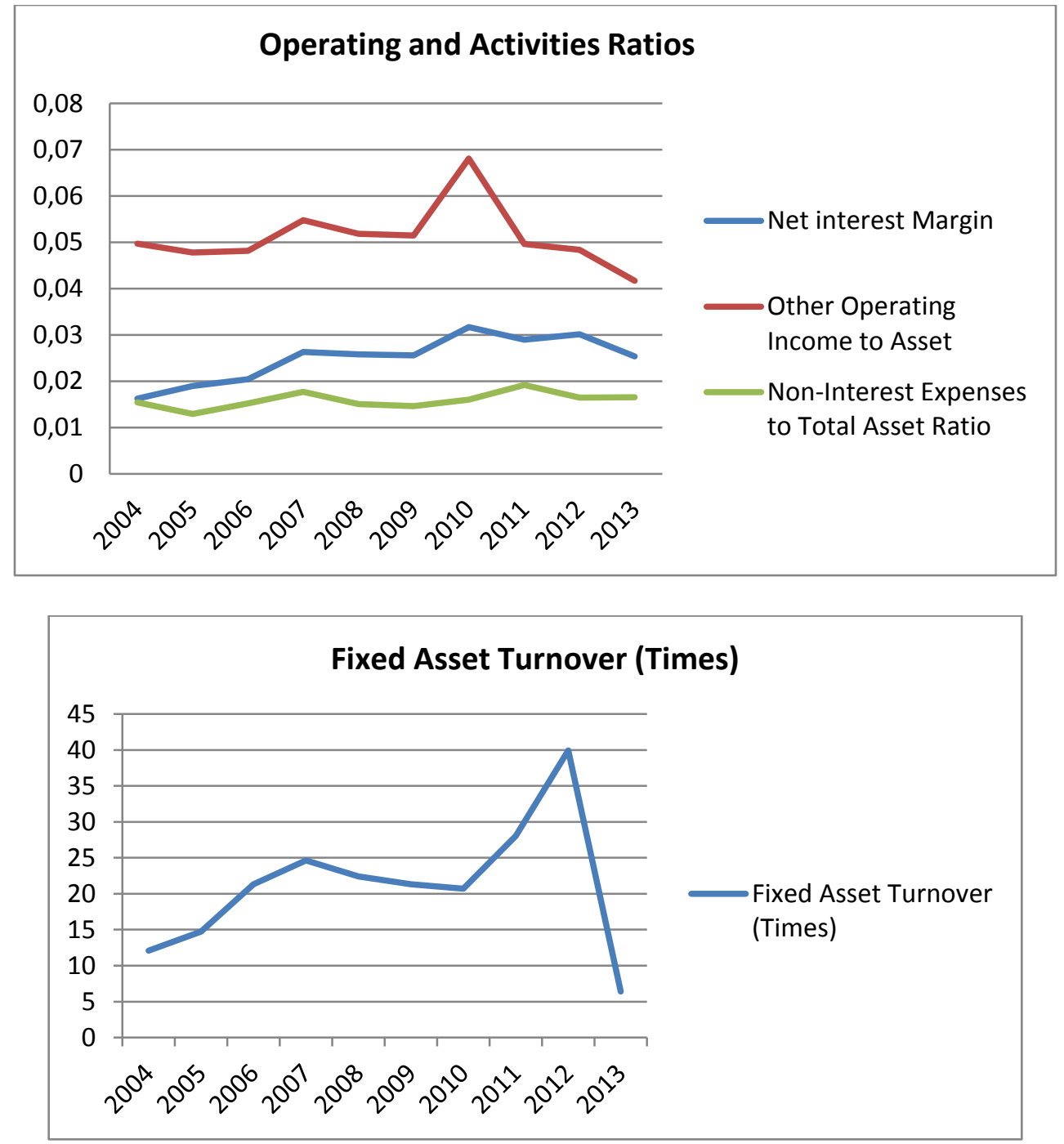

Net interest margin shows the net interest income to total assets. Higher net interest margin is good for the entity. In case of EXIM Bank Limited this ratio is upward sloping. Other operating income to total asset ratio shows the income to total asset arises from operation of the bank except interest income. If a bank is able to increase its operating income it is very good. But in case of this bank this ratio is downward sloping from the last three years. Other non-interest expenses to total asset ratio is upward sloping. The bank net fixed asset turnover was 12.07 times in FY 2004 but in 2013 the turnover is 6.41. This is showing their bad performance in operation. So, EXIM Bank Limited is not performing well.

\subsubsection{The City Bank Limited}

\section{Profitability Ratios}

To analyse profitability, six distinct ratios are considered. These are -

- Return on Asset

- Return on Equity

- Return on Capital Employed

- Gross Profit Margin

- Net Profit Margin and

- Operating Profit Margin 
Bijoy Chandra Das, Soma Rani Sutradhar

Econometric Study of Loan Classification of Commercial Banks in Bangladesh

Table 13: Profitability Ratios of City Bank Limited

\begin{tabular}{llllllll}
\hline Year & ROA & ROE & $\begin{array}{l}\text { Return } \\
\text { Capital } \\
\text { Employed Ratio }\end{array}$ & $\begin{array}{c}\text { On } \\
\text { Gross } \\
\text { Margin }\end{array}$ & $\begin{array}{l}\text { Profit } \\
\text { Net } \\
\text { Profit } \\
\text { Margin }\end{array}$ & $\begin{array}{l}\text { Operating } \\
\text { Profit Margin }\end{array}$ \\
\hline $\mathbf{2 0 0 4}$ & $1.44 \%$ & $26.83 \%$ & $3.50 \%$ & $88.30 \%$ & $21.01 \%$ & $45.48 \%$ \\
$\mathbf{2 0 0 5}$ & $1.75 \%$ & $27.62 \%$ & $4.39 \%$ & $86.25 \%$ & $22.11 \%$ & $46.23 \%$ \\
$\mathbf{2 0 0 6}$ & $0.58 \%$ & $9.48 \%$ & $2.03 \%$ & $70.26 \%$ & $6.36 \%$ & $17.31 \%$ \\
$\mathbf{2 0 0 7}$ & $0.71 \%$ & $11.95 \%$ & $2.93 \%$ & $61.49 \%$ & $8.21 \%$ & $19.33 \%$ \\
$\mathbf{2 0 0 8}$ & $0.75 \%$ & $9.44 \%$ & $2.82 \%$ & $75.18 \%$ & $8.53 \%$ & $21.72 \%$ \\
$\mathbf{2 0 0 9}$ & $1.23 \%$ & $13.96 \%$ & $3.03 \%$ & $76.06 \%$ & $14.26 \%$ & $24.17 \%$ \\
$\mathbf{2 0 1 0}$ & $2.21 \%$ & $16.05 \%$ & $4.88 \%$ & $102.98 \%$ & $26.08 \%$ & $42.30 \%$ \\
$\mathbf{2 0 1 1}$ & $1.95 \%$ & $11.30 \%$ & $2.61 \%$ & $82.38 \%$ & $21.44 \%$ & $36.84 \%$ \\
$\mathbf{2 0 1 2}$ & $0.62 \%$ & $4.25 \%$ & $0.87 \%$ & $68.79 \%$ & $6.13 \%$ & $14.17 \%$ \\
$\mathbf{2 0 1 3}$ & $0.66 \%$ & $4.92 \%$ & $0.97 \%$ & $65.35 \%$ & $6.69 \%$ & $13.27 \%$ \\
\hline
\end{tabular}

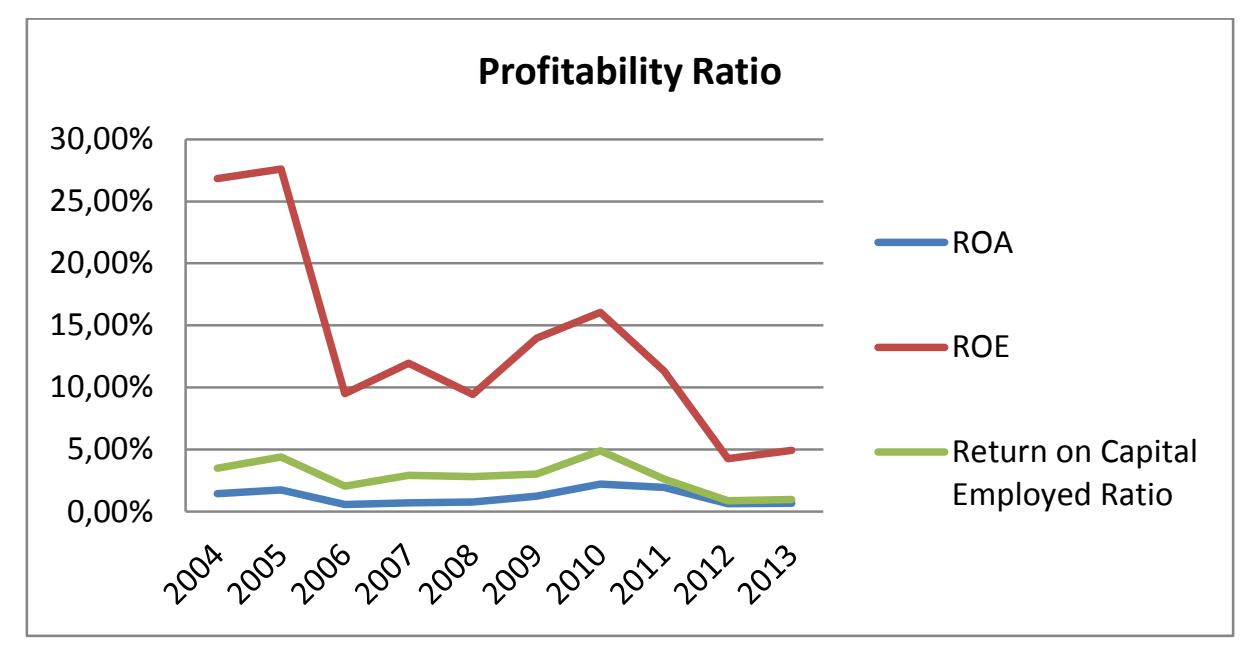

\section{Return on Asset}

ROA of City Bank Limited shows smaller fluctuations. In FY 2005 to FY 2008 the ROA was very closer. But in FY ROA is $0.66 \%$ i.e. it is comparatively lower than previous years which shows that the bank is not able to use their total assets in efficient manner.

\section{Return on Equity}

The ROE of AB Bank Limited fluctuated largely in different years. In spite of very high ROE (26.83\%) in FY 2004, ROE has decreased gradually. The Graph shows a downward trend of ROE. It measures that shareholder's value are decreasing over the periods.

\section{Return on Capital Employed Ratio}

The Return on Capital Employed ratio determines the return in respect of total amount of capital disbursed for loan and investment. This ratio is higher for FY 2010. But in the FY 2012 and FY 2013 it has decreased. Which indicates that bank is not employing its capital effectively. 


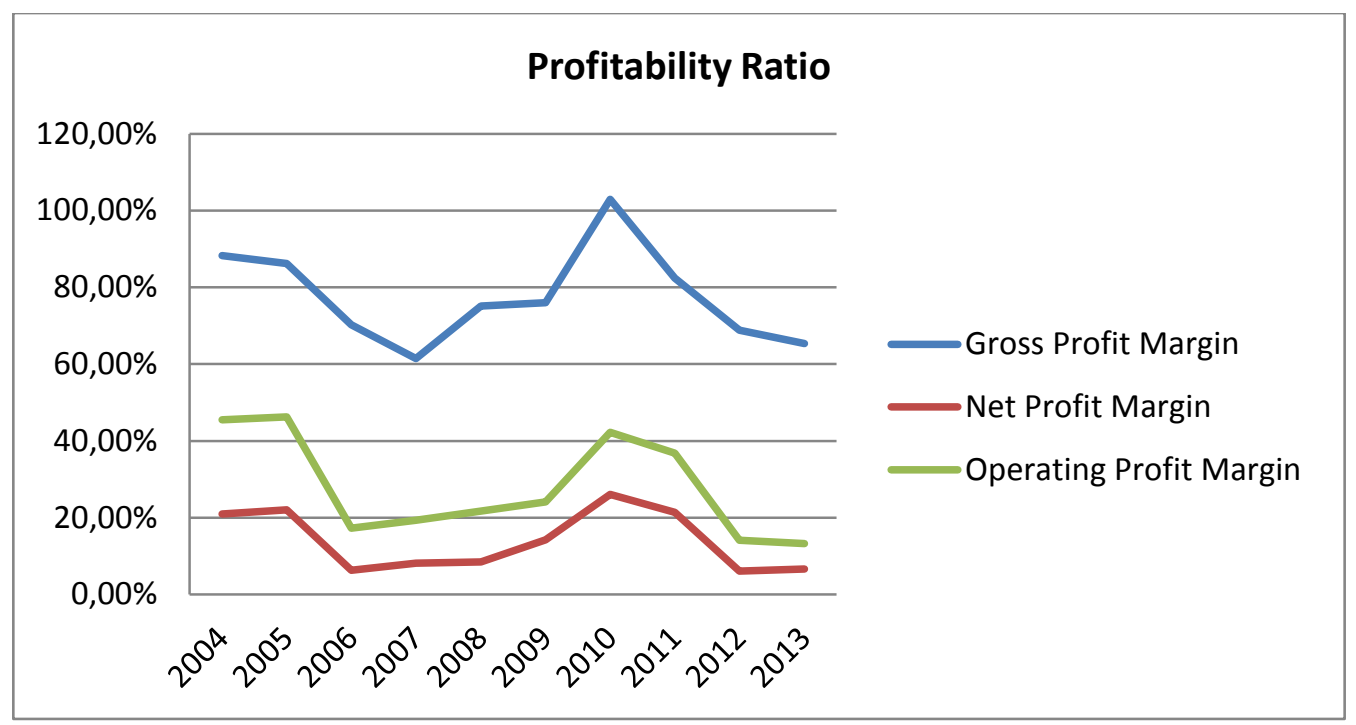

\section{Gross Profit Margin}

Gross profit margin shows the cost effectiveness of the entity. Gross Profit Margin was higher in FY $2010(102.98 \%)$ but in FY $2013(65.35 \%)$ it is smaller in respect of other periods. City Bank is not performing well in case of minimizing their cost of fund.

\section{Operating Profit Margin}

It shows the profitability after meeting the cost of fund and operating expenses. The bank is obtaining lower operating profit margin. It means increasing operating expenses and cost of fund.

\section{Net Profit Margin}

The same thing like gross profit margin and operating profit margin is happening in case of Net Profit Margin. The bank is not performing in case of earning profit.

\section{Liquidity Ratios}

To analyse liquidity of $A B$ Bank Limited, following ratios will be considered.

- Current Ratio

- Current Asset Ratio

- Loan Deposit Ratio

Table 14: Liquidity Ratios of City Bank Limited

\begin{tabular}{|c|c|c|c|c|c|}
\hline Year & Current Ratio & $\begin{array}{l}\text { Current } \\
\text { Ratio }\end{array}$ & Asset & $\begin{array}{l}\text { Loan } \\
\text { Ratio }\end{array}$ & Deposit \\
\hline 2004 & $14.35 \%$ & $69.65 \%$ & & $76.57 \%$ & \\
\hline 2005 & $9.33 \%$ & $63.06 \%$ & & $76.11 \%$ & \\
\hline 2006 & $10.76 \%$ & $59.55 \%$ & & $75.31 \%$ & \\
\hline 2007 & $20.38 \%$ & $55.92 \%$ & & $66.08 \%$ & \\
\hline 2008 & $17.08 \%$ & $50.67 \%$ & & $76.43 \%$ & \\
\hline 2009 & $24.03 \%$ & $52.55 \%$ & & $69.71 \%$ & \\
\hline 2010 & $13.02 \%$ & $73.84 \%$ & & $89.48 \%$ & \\
\hline 2011 & $10.26 \%$ & $62.43 \%$ & & $91.64 \%$ & \\
\hline 2012 & $11.99 \%$ & $68.57 \%$ & & $88.56 \%$ & \\
\hline 2013 & $12.95 \%$ & $64.68 \%$ & & $83.61 \%$ & \\
\hline
\end{tabular}




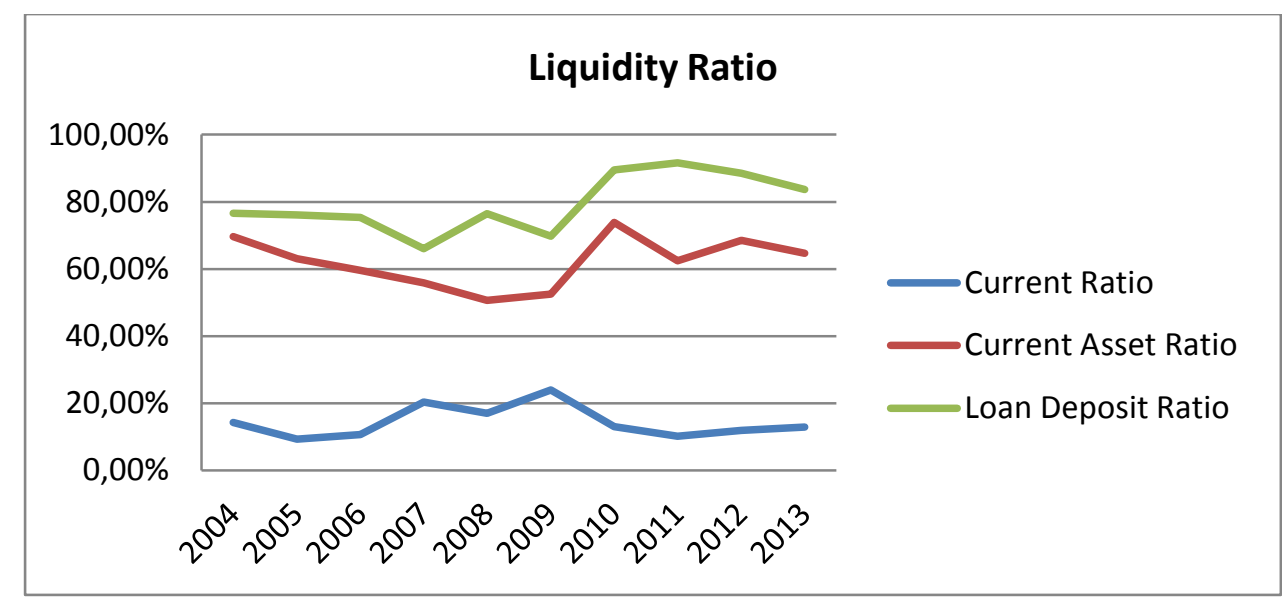

\section{Current Ratio}

It shows the liquidity in terms of cash balance at hand and balance with other banks. The bank is maintaining a near consistent current ratio (\%).

\section{Current Asset Ratio}

It measures the total cash and other liquid assets to total deposits. The bank is maintaining a good current asset ratio.

\section{Loan Deposit Ratio}

The bank has an increasing trend in loan deposit ratio. The bank is increasing its loan deposit ratio. Combining all the liquidity ratios together, it seems that the bank is performing well in maintaining liquidity. And the bank is able to meet the current liabilities.

\section{Risk and Solvency Ratio}

To comment on risk and solvency ratio, the following ratios are to be considered.

- Debt to equity ratio

- Debt to total asset ratio

- Financial leverage ratio

Table 15: Risk and Solvency Ratio of City Bank Limited

\begin{tabular}{|c|c|c|c|c|c|}
\hline Year & Debt to Equity Ratio & $\begin{array}{l}\text { Debt to } \\
\text { Ratio }\end{array}$ & Total Asset & $\begin{array}{l}\text { Financial } \\
\text { Ratio }\end{array}$ & Leverage \\
\hline 2004 & $477.77 \%$ & $94.63 \%$ & & $112 \%$ & \\
\hline 2005 & $391.49 \%$ & $94.45 \%$ & & $110 \%$ & \\
\hline 2006 & $207.20 \%$ & $94.67 \%$ & & $229 \%$ & \\
\hline 2007 & $151.35 \%$ & $94.10 \%$ & & $155 \%$ & \\
\hline 2008 & $100.83 \%$ & $92.62 \%$ & & $173 \%$ & \\
\hline 2009 & $237.91 \%$ & $92.33 \%$ & & $163 \%$ & \\
\hline 2010 & $149.40 \%$ & $87.33 \%$ & & $137 \%$ & \\
\hline 2011 & $266.94 \%$ & $84.57 \%$ & & $121 \%$ & \\
\hline 2012 & $314.55 \%$ & $86.20 \%$ & & $259 \%$ & \\
\hline 2013 & $332.26 \%$ & $87.44 \%$ & & $230 \%$ & \\
\hline
\end{tabular}

For analysing risk and solvency, it is seen that debt to equity ratio is fluctuated very highly for the periods. As the debt to equity ratio is decreasing in different years, riskiness of being default is low. The debt to total asset ratio is near constant. The fluctuation is very low. Financial leverage ratio 
shows the profitability due to use of debt. Combining all together, the ratios show that the bank is able to minimize risk and solvent enough to meet the liabilities.

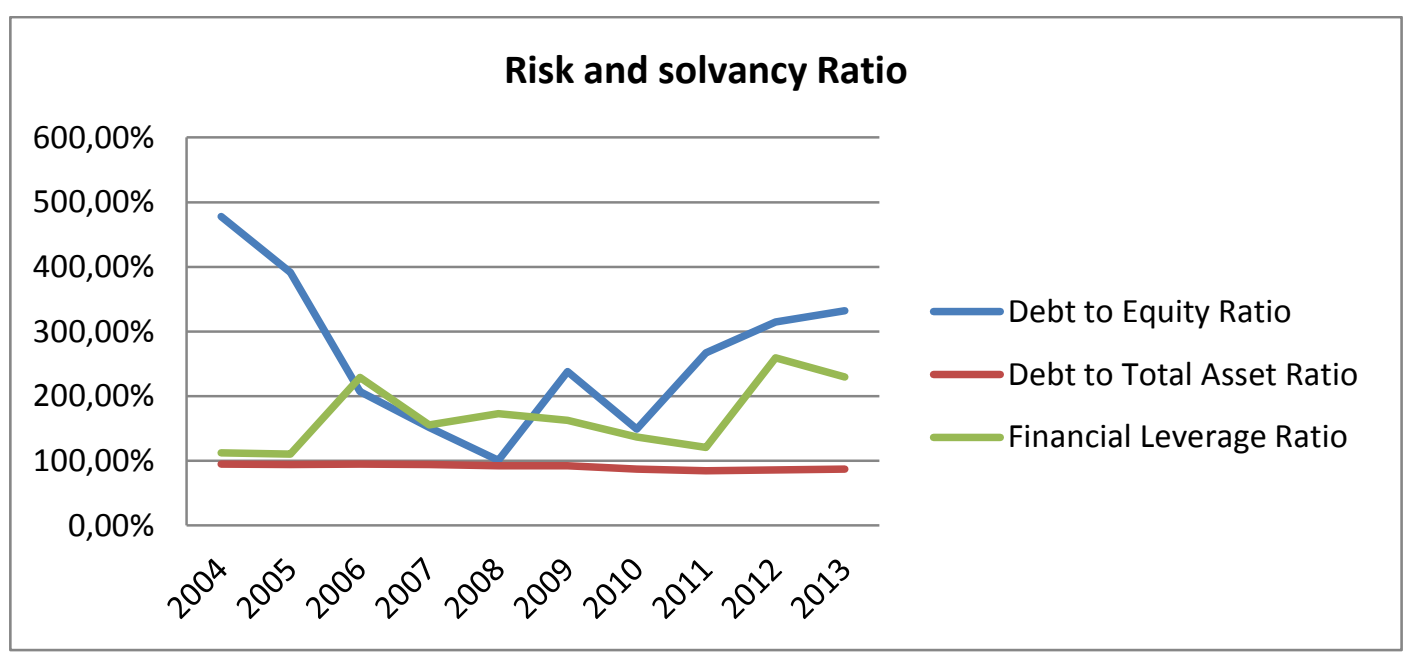

\section{Operating and activities ratios}

For operating and activities ratios, following ratios are to be considered.

- Net interest margin ratio

- Other operating income to asset ratio

- Non-Interest expenses to total asset ratio

- Fixed asset turnover

Table 16: Operating and activities ratios of City Bank Limited

\begin{tabular}{|c|c|c|c|c|c|}
\hline Year & $\begin{array}{l}\text { Net } \\
\text { interest } \\
\text { Margin }\end{array}$ & $\begin{array}{l}\text { Other Operating } \\
\text { Income to Asset }\end{array}$ & $\begin{array}{l}\text { Non-Interest } \\
\text { Expenses to Total } \\
\text { Asset Ratio }\end{array}$ & $\begin{array}{l}\text { Fixed } \\
\text { Turnover }\end{array}$ & Asset \\
\hline 2004 & $2.65 \%$ & $6.06 \%$ & $3 \%$ & 2.65 & \\
\hline 2005 & $10.80 \%$ & $5.98 \%$ & $2 \%$ & 3.20 & \\
\hline 2006 & $2.54 \%$ & $5.59 \%$ & $2 \%$ & 2.94 & \\
\hline 2007 & $1.94 \%$ & $5.28 \%$ & $3 \%$ & 3.01 & \\
\hline 2008 & $2.64 \%$ & $6.15 \%$ & $3 \%$ & 1.86 & \\
\hline 2009 & $2.71 \%$ & $5.71 \%$ & $3 \%$ & 2.06 & \\
\hline 2010 & $3.93 \%$ & $8.03 \%$ & $4 \%$ & 2.21 & \\
\hline 2011 & $3.82 \%$ & $6.70 \%$ & $3 \%$ & 1.58 & \\
\hline 2012 & $3.66 \%$ & $6.58 \%$ & $3 \%$ & 2.10 & \\
\hline 2013 & $3.40 \%$ & $6.03 \%$ & $3 \%$ & 2.00 & \\
\hline
\end{tabular}

In City Bank Limited, from year 2004 to 2013 net interest margin ratio were merely fluctuated. Here the net interest margin decreased from year to year and after 2009 it was quite stable but not quite good. The earnings of City Bank Limited in proportion to its assets are low which results that the less effectively Other non-interest expenses to total asset ratio was not fluctuated too much for last 10 years. The bank net fixed asset turnover was decreasing from year to year which is alarming for the bank. This is showing their bad performance in operation. 
Bijoy Chandra Das, Soma Rani Sutradhar

Econometric Study of Loan Classification of Commercial Banks in Bangladesh

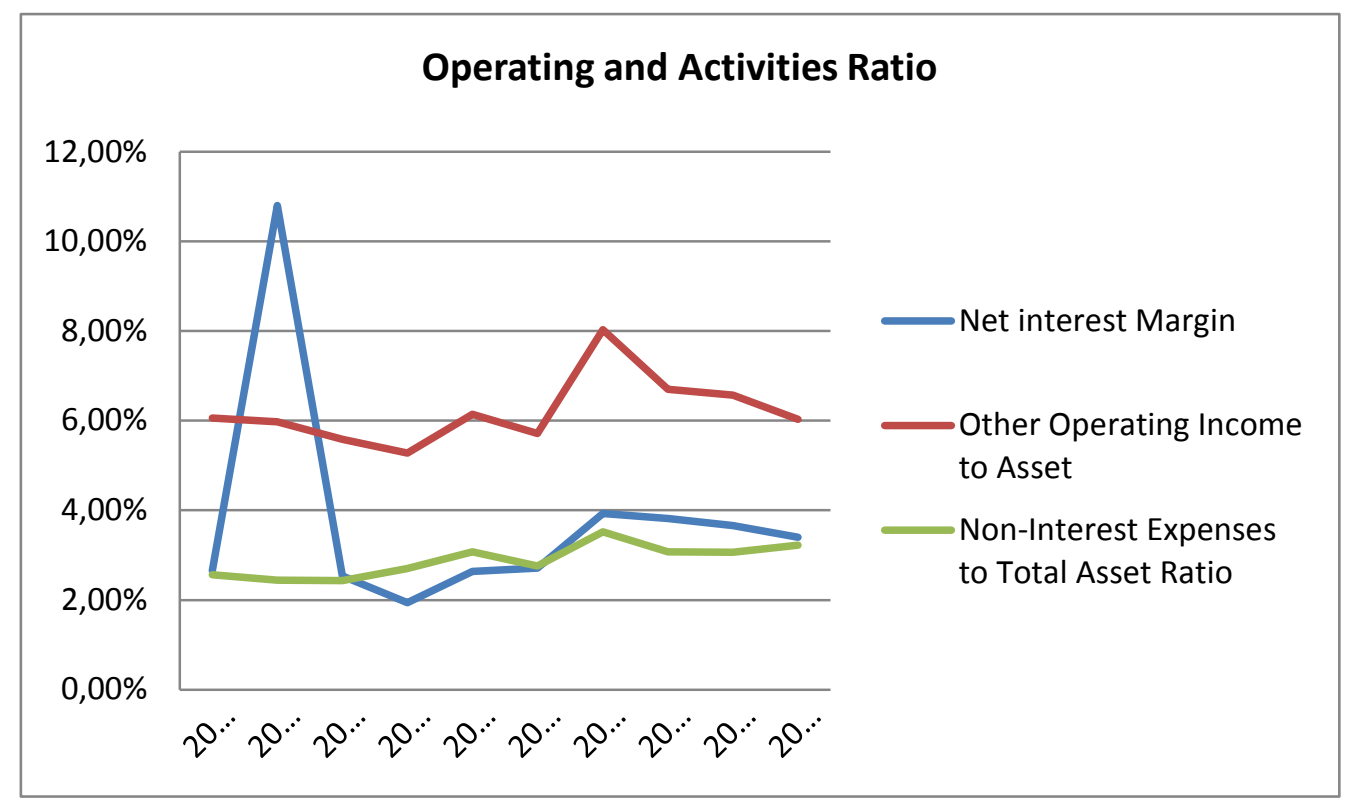

\subsubsection{United Commercial Bank Limited Profitability Ratios}

There are six distinct ratios those are considered to analyze the profitability. These are -

- Return on Asset

- Return on Equity

- Return on Capital Employed

- Gross Profit Margin

- Net Profit Margin and

- Operating Profit Margin

Table 17: Profitability Ratios of United Commercial Bank Limited

\begin{tabular}{llllllll}
\hline Year & ROA & ROE & $\begin{array}{l}\text { Return } \\
\text { Capital } \\
\text { Employed Ratio }\end{array}$ & $\begin{array}{l}\text { on } \\
\text { Gross Profit } \\
\text { Margin }\end{array}$ & $\begin{array}{l}\text { Net } \\
\text { Margin }\end{array}$ & $\begin{array}{l}\text { Profit } \\
\text { Operating } \\
\text { Margit }\end{array}$ \\
\hline $\mathbf{2 0 0 4}$ & $0.67 \%$ & $13.55 \%$ & $2.10 \%$ & $210.81 \%$ & $22.46 \%$ & $83.51 \%$ \\
$\mathbf{2 0 0 5}$ & $1.55 \%$ & $24.04 \%$ & $3.88 \%$ & $179.75 \%$ & $37.62 \%$ & $76.90 \%$ \\
$\mathbf{2 0 0 6}$ & $1.73 \%$ & $25.05 \%$ & $3.60 \%$ & $184.01 \%$ & $45.20 \%$ & $82.32 \%$ \\
$\mathbf{2 0 0 7}$ & $1.84 \%$ & $25.98 \%$ & $4.90 \%$ & $204.24 \%$ & $50.08 \%$ & $102.47 \%$ \\
$\mathbf{2 0 0 8}$ & $1.33 \%$ & $17.44 \%$ & $3.71 \%$ & $204.60 \%$ & $38.07 \%$ & $72.84 \%$ \\
$\mathbf{2 0 0 9}$ & $1.20 \%$ & $16.35 \%$ & $4.00 \%$ & $198.39 \%$ & $35.65 \%$ & $58.92 \%$ \\
$\mathbf{2 0 1 0}$ & $1.98 \%$ & $27.92 \%$ & $7.28 \%$ & $204.77 \%$ & $56.90 \%$ & $94.71 \%$ \\
$\mathbf{2 0 1 1}$ & $1.97 \%$ & $18.43 \%$ & $6.10 \%$ & $180.53 \%$ & $57.22 \%$ & $100.48 \%$ \\
$\mathbf{2 0 1 3}$ & $0.84 \%$ & $8.73 \%$ & $3.51 \%$ & $153.89 \%$ & $23.99 \%$ & $56.54 \%$ \\
\hline
\end{tabular}




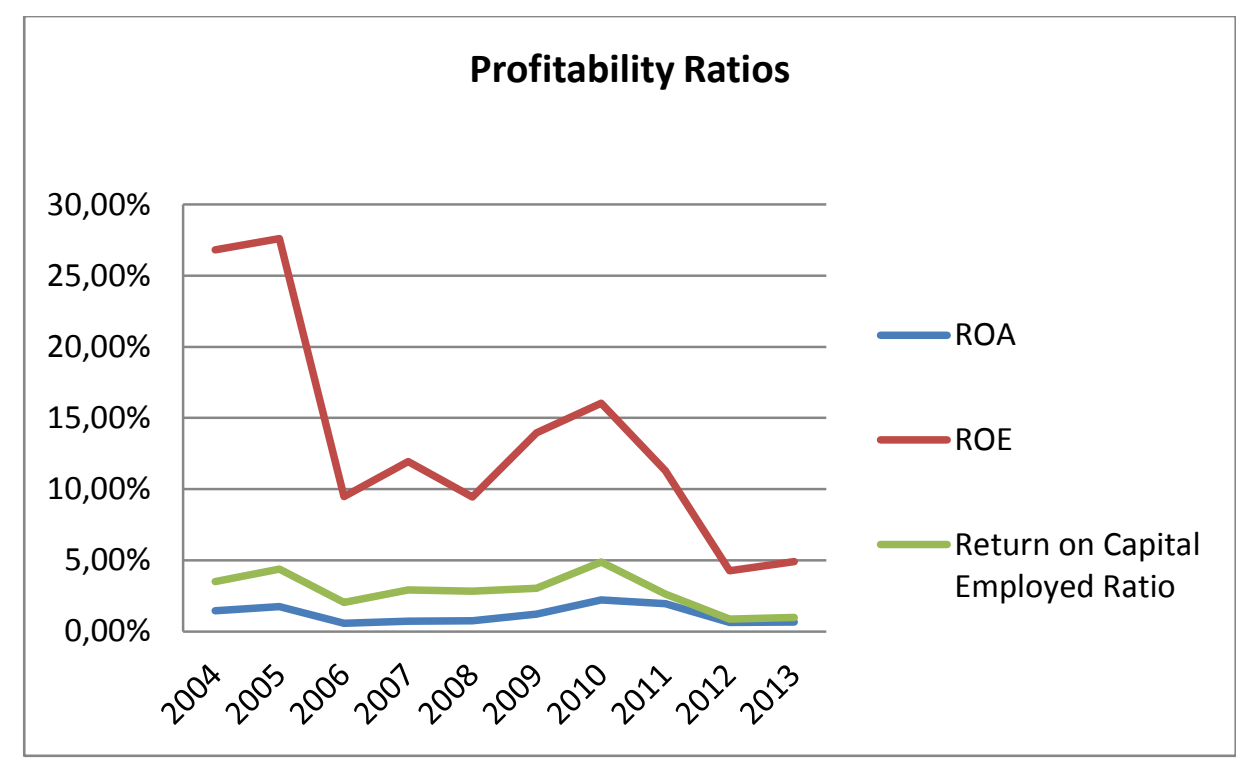

\section{Return on Asset}

ROA of UCBL shows smaller fluctuations. In FY 2005 to FY 2009 the ROA was very closer. In There are ups and downs in different FY. But in FY 2013 it declined to 1.41\%, which shows that the bank is not able to use their total assets in efficient manner.

\section{Return on Equity}

The ROE of UCBL fluctuated largely in different years. The highest ROE was $27.92 \%$ in FY 2010. It has decreased gradually after FY 2010.The Graph shows a downward trend of ROE. It measures that shareholder's value are decreasing over the periods.

\section{Return on Capital Employed Ratio}

The Return on Capital Employed ratio determines the return in respect of total amount of capital disbursed for loan and investment. This ratio is higher for 2010 (7.28\%). But from 2011 to 2013 it has decreased.

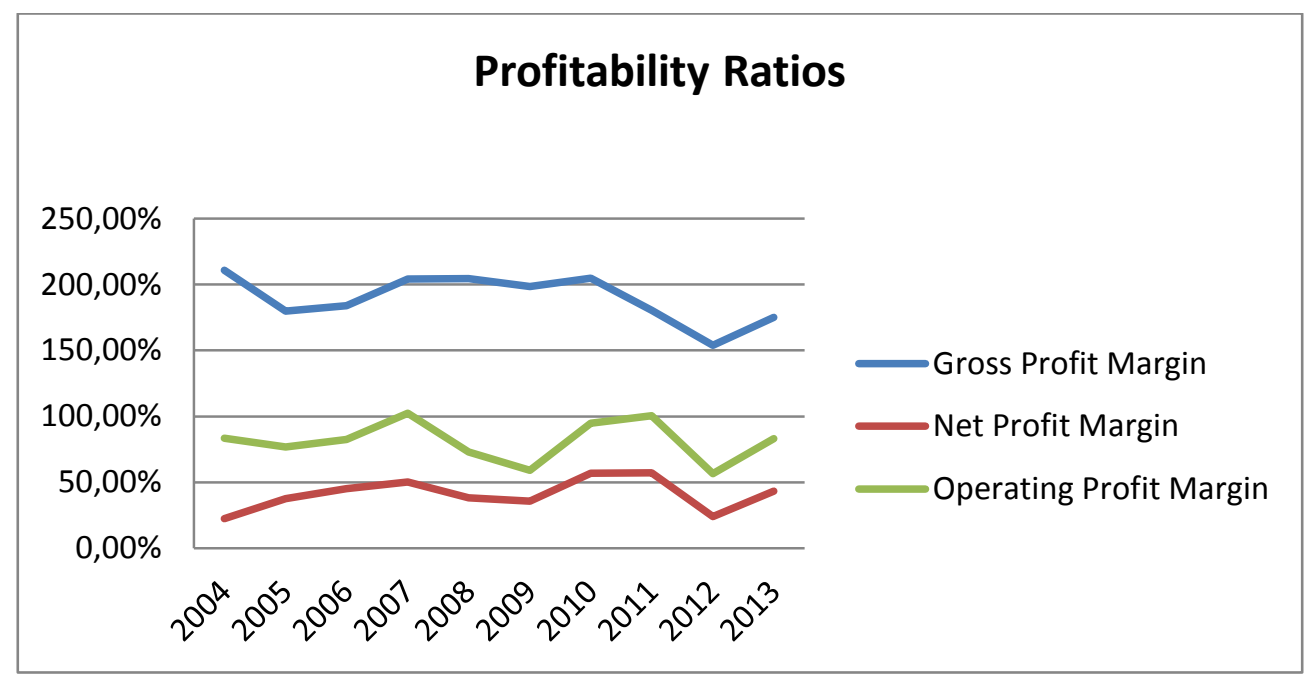

\section{Gross Profit Margin}

Gross profit margin shows the cost effectiveness of the entity. Gross Profit Margin was the highest in FY 2004 but gradually it has declined. In FY 2013 it is smaller in respect of other periods. UCBL is not performing well in case of minimizing their cost of fund. 


\section{Net Profit Margin}

Net profit margin has increased gradually. The bank is performing well in case of earning profit. In 2013 it was $43.30 \%$.

\section{Operating Profit Margin}

It shows the profitability after meeting the cost of fund and operating expenses. The bank is obtaining high operating profit margin. It means decreasing operating expenses and cost of fund.

\section{Liquidity Ratios}

To analyze liquidity of UCBL, the following ratios will be considered.

- Current Ratio

- Current Asset Ratio

- Loan Deposit Ratio

Table 18: Liquidity Ratios of United Commercial Bank Limited

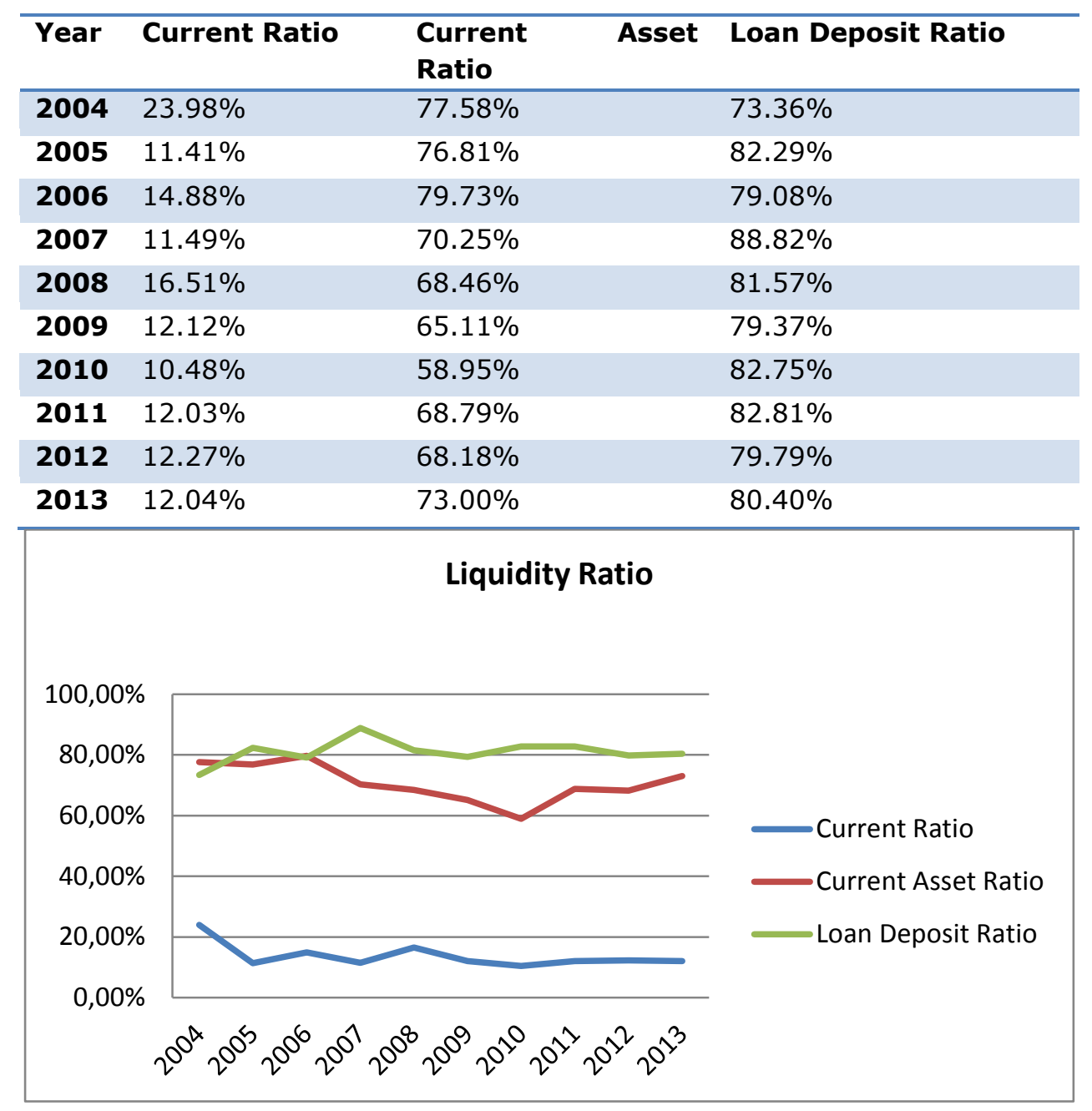

\section{Current Ratio}

It shows the liquidity in terms of cash balance at hand and balance with other banks. The bank is maintaining a near consistent current ratio after 2004 where it was the highest ratio of $23.98 \%$. The average current ratio is $13.72 \%$.

\section{Current Asset Ratio}


It measures the total cash and other liquid assets to total deposits. The bank is maintaining a good current asset ratio. The average current asset ratio is $70.68 \%$.

\section{Loan Deposit Ratio}

The bank is maintaining an increasing trend in loan deposit ratio. It keeps a good deposit collection against loan. The average loan deposit ratio is $80.72 \%$.

From the above liquidity ratios together, it seems that the bank is performing well in maintaining liquidity. It is proficient to congregate its current liabilities.

\section{Risk and Solvency Ratio}

The following ratios are to be considered to comment on risk and solvency ratio.

- Debt to equity ratio

- Debt to total asset ratio

- Financial leverage ratio

Table 19: Risk and Solvency Ratio of United Commercial Bank Limited

\begin{tabular}{lllll}
\hline Year & Debt to Equity Ratio & $\begin{array}{l}\text { Debt to } \\
\text { Ratio }\end{array}$ & $\begin{array}{l}\text { Total } \\
\text { Asset }\end{array}$ & $\begin{array}{l}\text { Financial } \\
\text { Ratio }\end{array}$ \\
\hline $\mathbf{2 0 0 4}$ & $322.07 \%$ & $95.04 \%$ & $136.92 \%$ \\
\hline $\mathbf{2 0 0 5}$ & $375.57 \%$ & $93.98 \%$ & $135.19 \%$ \\
$\mathbf{2 0 0 6}$ & $469.11 \%$ & $93.98 \%$ & $124.64 \%$ \\
$\mathbf{2 0 0 7}$ & $289.08 \%$ & $93.75 \%$ & $120.99 \%$ \\
$\mathbf{2 0 0 8}$ & $235.27 \%$ & $93.23 \%$ & $167.46 \%$ \\
$\mathbf{2 0 0 9}$ & $195.28 \%$ & $93.69 \%$ & $202.69 \%$ \\
$\mathbf{2 0 1 0}$ & $168.76 \%$ & $93.98 \%$ & $130.30 \%$ \\
\hline $\mathbf{2 0 1 1}$ & $118.11 \%$ & $90.54 \%$ & $115.47 \%$ \\
$\mathbf{2 0 1 2}$ & $52.19 \%$ & $91.24 \%$ & $154.11 \%$ \\
\hline $\mathbf{2 0 1 3}$ & $309.18 \%$ & $90.94 \%$ & $121.05 \%$ \\
\hline
\end{tabular}

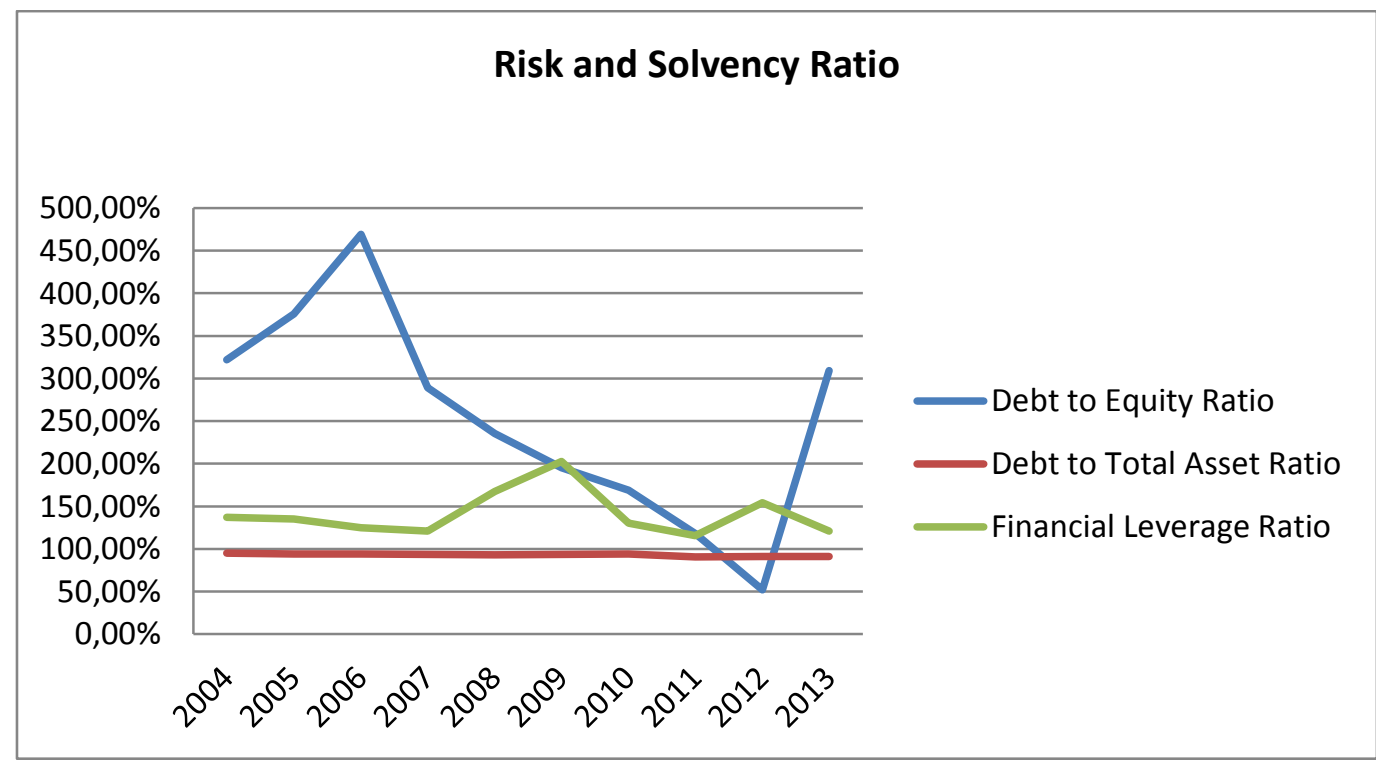

After analysing the data of risk and solvency, it is seen that, there is a decrease trend in debt to equity ratio after 2006. Where there was the highest ratio. It has decreased continuously to 2012 . In 2013 the debt to equity ratio jumped to $52.19 \%$ to $309.18 \%$ in one year different. The debt to total asset ratio is near constant. The fluctuation is very low. Financial leverage ratio shows the profitability 
due to use of debt. The bank is maintaining a reasonable leverage that is $141.35 \%$ in an average. Combining all together, the ratios show that the bank is able to minimize risk and solvent enough to meet the liabilities.

\section{Operating and Activities Ratios}

Following ratios are to be analysed to comment on operating and activities ratios.

- Net interest margin ratio

- Other operating income to asset ratio

- Non-Interest expenses to total asset ratio

- $\quad$ Fixed asset turnover

Table 20: Operating and Activities Ratios of United Commercial Bank Limited

\begin{tabular}{|c|c|c|c|c|c|c|}
\hline Year & $\begin{array}{l}\text { Net interest } \\
\text { Margin }\end{array}$ & $\begin{array}{l}\text { Other Operating } \\
\text { Income to Asset }\end{array}$ & $\begin{array}{l}\text { Non-Interest } \\
\text { Expenses to } \\
\text { Asset Ratio }\end{array}$ & Total & $\begin{array}{l}\text { Fixed } \\
\text { Turnover }\end{array}$ & Asset \\
\hline 2004 & $2.99 \%$ & $6.31 \%$ & $2.89 \%$ & & 6.27 & \\
\hline 2005 & $3.85 \%$ & $6.92 \%$ & $2.92 \%$ & & 8.30 & \\
\hline 2006 & $3.34 \%$ & $6.14 \%$ & $2.72 \%$ & & 10.43 & \\
\hline 2007 & $3.24 \%$ & $6.63 \%$ & $2.60 \%$ & & 10.31 & \\
\hline 2008 & $3.10 \%$ & $6.34 \%$ & $2.56 \%$ & & 5.75 & \\
\hline 2009 & $2.89 \%$ & $5.74 \%$ & $2.28 \%$ & & 5.33 & \\
\hline 2010 & $2.95 \%$ & $6.05 \%$ & $2.40 \%$ & & 4.82 & \\
\hline 2011 & $3.05 \%$ & $5.50 \%$ & $1.97 \%$ & & 4.67 & \\
\hline 2012 & $3.19 \%$ & $4.91 \%$ & $2.13 \%$ & & 4.08 & \\
\hline 2013 & $3.13 \%$ & $5.48 \%$ & $2.33 \%$ & & 2.89 & \\
\hline
\end{tabular}
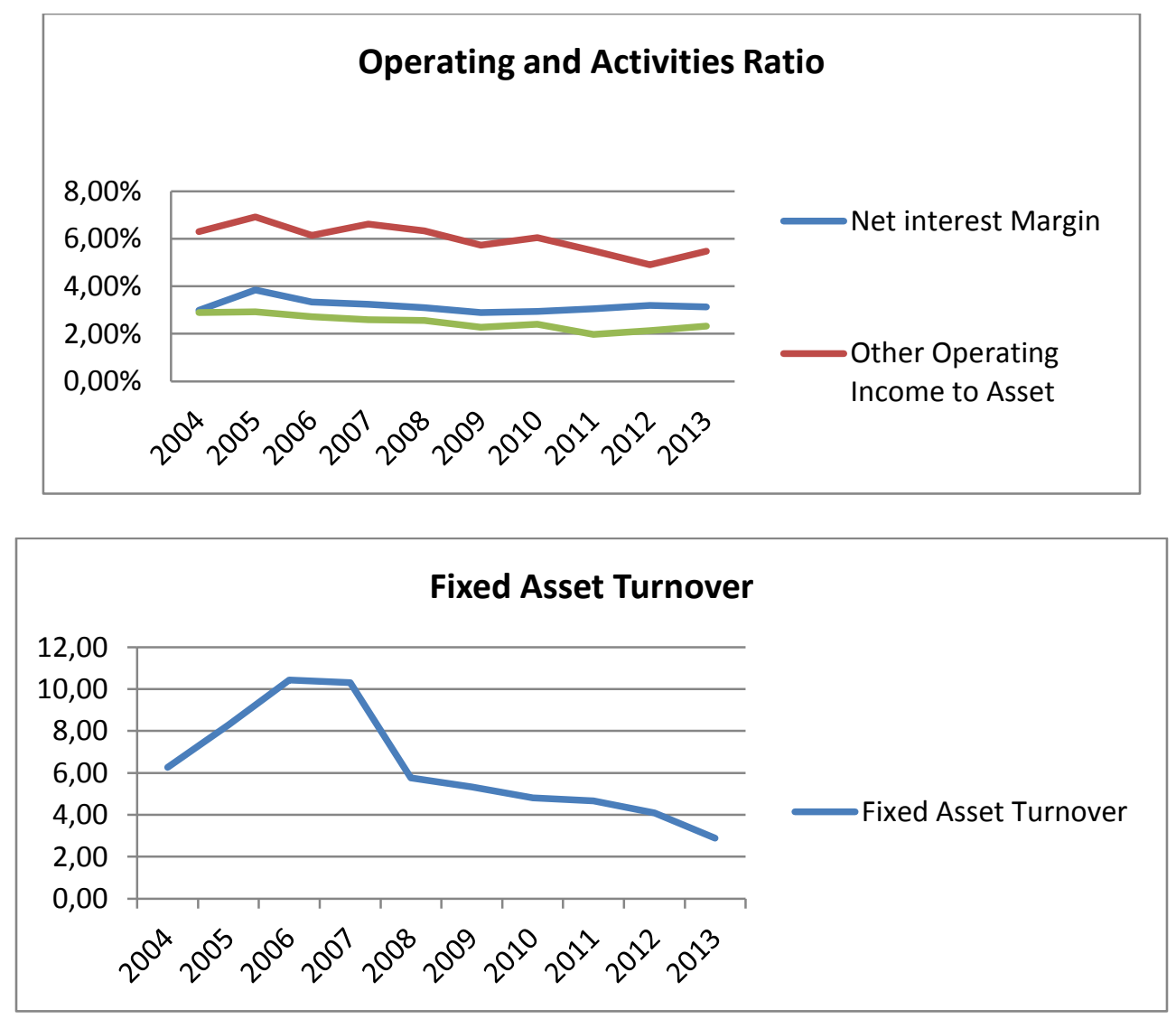
Net interest margin shows the net interest income to total assets. Higher net interest margin is good for the entity. In case of UCBL it has an average ratio of $3.45 \%$. Other operating income to total asset ratio shows the income to total asset has very closer trend. Average is $6.35 \%$. But it If a bank is able to increase its operating income it is very good. Other non-interest expenses to total asset ratio is decreasing. The bank's net fixed asset turnover was 10.43 times in FY 2006. But it has decreased after FY 2008 to FY 2013. This is showing their bad performance in operation. So, UCBL is not performing well in income to net fixed asset.

\subsection{Regression Analysis}

\subsubsection{AB Bank Limited}

Regressing the regression equation, we get -

Loan $=-3.982+1.028 \times$ Deposit $+(-1.668) \times C I H+(-0.844) \times B W O B$

Goodness of Fit: The adjusted $R^{2}$ value is 0.977 shows that the $97.7 \%$ of total variation in explained variable $y$ that is loan can be explained by the regression model. So, the sample regression gives the best fit.

Parameters: The coefficient of deposit 1.028 measures that deposit is positively correlated with loan and holding other variables constant, if deposit goes up by 1 in a year, loan will increase by 1.028 times of deposit with a significance level of $0.5 \%$. The coefficient of $\mathrm{CIH}-1.668$ measures that cash in hand is negatively correlated with loan and holding other variables constant if $\mathrm{CIH}$ goes up by 1 loan will decrease by 1.668 times of $\mathrm{CIH}$ with a significance level of $68.6 \%$. The coefficient of BWOB -0.844 shows that BWOB is negatively related with loan and holding other variables constant if BWOB increases by 1 loan will decrease by 0.844 times of BWOB with $69.1 \%$ significance level.

Test of Hypothesis: To test acceptation or rejection of null hypothesis, $\mathrm{p}$ value will be considered. In this regression output $p$ value or significance level is 0.0000001 which is much less than 0.005 . So, null hypothesis will not be accepted. It can be concluded that there is a linear relation among the explained and explanatory variables.

\subsubsection{The City Bank Limited}

Regressing the regression equation, we get -

Loan $=-5.434+1.171 \times$ Deposit $+(-2.181) \times C I H+(-1.358) \times B W O B$

Goodness of Fit: The adjusted $R^{2}$ value is 0.989 shows that the $98.9 \%$ of total variation in explained variable $y$ that is loan can be explained by the regression model. So, the sample regression gives the best fit.

Parameters: The coefficient of deposit 1.171 measures that deposit is positively correlated with loan and holding other variables constant, if deposit goes up by 1 in a year, loan will increase by 1.171 times of deposit with a significance level of $0.8 \%$. The coefficient of $\mathrm{CIH}-2.181$ measures that cash in hand is negatively correlated with loan and holding other variables constant if CIH goes up by 1 loan will decrease by 2.181 times of $\mathrm{CIH}$ with a significance level of $48.2 \%$. The coefficient of BWOB -1.358 shows that BWOB is negatively related with loan and holding other $0.9 \%$ significance level.

Test of Hypothesis: To test acceptation or rejection of null hypothesis, $\mathrm{p}$ value will be considered. In this regression output $p$ value of significance level is 0.0000001 which is much less than 0.005 . So, null hypothesis will not be accepted. It can be concluded that there is a linear relation among the explained and explanatory variables.

\subsubsection{EXIM Bank Limited}

Regressing the regression equation, we get -

Loan $=-0.169+0.032 \times$ Deposit $+0.117 \times \mathrm{CIH}+0.419 \times B W O B$ 
Goodness of Fit: The adjusted $R^{2}$ value is 0.952 shows that the $95.2 \%$ of total variation in explained variable $y$ that is loan can be explained by the regression model. So, the sample regression gives the best fit.

Parameters: The coefficient of deposit 0.032 measures that deposit is positively correlated with loan and holding other variables constant, if deposit goes up by 1 in a year, loan will increase by 0.032 times of deposit with a significance level of $20.5 \%$. The coefficient of CIH 0.117 measures that cash in hand is positively correlated with loan and holding other variables constant if CIH goes up by 1 loan will increase by 0.117 times of $\mathrm{CIH}$ with a significance level of $43.1 \%$. The coefficient of BWOB 0.419 shows that BWOB is positively correlated with loan and holding other variables constant if BWOB increases by 1 loan will increase by 0.419 times of BWOB with $6.6 \%$ significance level.

Test of Hypothesis: To test acceptation or rejection of null hypothesis, $\mathrm{p}$ value will be considered. In this regression output $p$ value or significance level is 0.00006912 which is much less than 0.005 . So, null hypothesis will not be accepted. It can be concluded that there is a linear relation among the explained and explanatory variables.

\subsubsection{Prime Bank Limited}

Regressing the regression equation, we get -

Loan $=-0.387+0.932 \times$ Deposit $+(-1.223) \times C I H+1.410 \times B W O B$

Goodness of Fit: The adjusted $R^{2}$ value is 0.976 shows that the $97.6 \%$ of total variation in explained variable $y$ that is loan can be explained by the regression model. So, the sample regression gives the best fit.

Parameters: The coefficient of deposit 0.932 measures that deposit is positively correlated with loan and holding other variables constant, if deposit goes up by 1 in a year, loan will increase by 0.932 times of deposit with a significance level of $6.20 \%$. The coefficient of CIH -1.223 measures that cash in hand is negatively correlated with loan and holding other variables constant if $\mathrm{CIH}$ goes up by 1 loan will decrease by 1.223 times of $\mathrm{CIH}$ with a significance level of $79.8 \%$. The coefficient of BWOB 1.410 shows that BWOB is positively correlated with loan and holding other variables constant if BWOB increases by 1 loan will increase by 1.410 times of BWOB with $76.9 \%$ significance level.

Test of Hypothesis: To test acceptation or rejection of null hypothesis, $\mathrm{p}$ value will be considered. In this regression output $p$ value or significance level is 0.00008701 which is much less than 0.005 . So, null hypothesis will not be accepted. It can be concluded that there is a linear relation among the explained and explanatory variables.

\subsubsection{United Commercial Bank Limited}

Regressing the regression equation, we get -

Loan $=0.708+0.850 \times$ Deposit $+(-0.209) \times C I H+(-0.882) \times B W O B$

Goodness of Fit: The adjusted $R^{2}$ value is 0.998 shows that the $99.8 \%$ of total variation in explained variable $y$ that is loan can be explained by the regression model. So, the sample regression gives the best fit.

Parameters: The coefficient of deposit 0.850 measures that deposit is positively correlated with loan and holding other variables constant, if deposit goes up by 1 in a year, loan will increase by 0.850 times of deposit with a significance level of $0.1 \%$. The coefficient of CIH -0.209 measures that cash in hand is negatively correlated with loan and holding other variables constant if CIH goes up by 1 loan will decrease by 0.209 times of $\mathrm{CIH}$ with a significance level of $0.898 \%$. The coefficient of BWOB 0.882 shows that BWOB is negatively correlated with loan and holding other variables constant if BWOB increases by 1 loan will decrease by 0.882 times of BWOB with $23.9 \%$ significance level. 
Test of Hypothesis: To test acceptation or rejection of null hypothesis, $\mathrm{p}$ value will be considered. In this regression output $p$ value or significance level is 0.00007123 which is much less than 0.005 . So, null hypothesis will not be accepted. It can be concluded that there is a linear relation among the explained and explanatory variables.

\subsubsection{Comparative Analysis of the regression results of the sample banks}

\begin{tabular}{|c|c|c|c|c|c|c|c|c|c|c|}
\hline $\begin{array}{l}\text { Banks } \\
\text { Parameters }\end{array}$ & $A B$ & L.S & City & L.S & Exim & L.S & Prime & L.S & UCBL & L.S \\
\hline Loan $\rightarrow$ Deposit & 1.028 & $0.5 \%$ & 1.171 & $0.8 \%$ & 0.032 & $\begin{array}{l}20.5 \\
\%\end{array}$ & 0.932 & $\begin{array}{l}6.20 \\
\%\end{array}$ & 0.850 & $0.1 \%$ \\
\hline Loan $\rightarrow \mathrm{CIH}$ & $\begin{array}{l}- \\
1.668\end{array}$ & $\begin{array}{l}68.6 \\
\%\end{array}$ & $\begin{array}{l}-181 \\
2.181\end{array}$ & $48.2 \%$ & 0.117 & $\begin{array}{l}43.1 \\
\%\end{array}$ & $\begin{array}{l}- \\
1.223\end{array}$ & $\begin{array}{l}79.8 \\
\%\end{array}$ & $-\overline{0}$ & $\begin{array}{l}0.898 \\
\%\end{array}$ \\
\hline Loan $\rightarrow$ BWOB & $\begin{array}{l}- \\
0.844\end{array}$ & $\begin{array}{l}69.1 \\
\%\end{array}$ & $\begin{array}{l}- \\
1.358\end{array}$ & $0.9 \%$ & 0.419 & $6.6 \%$ & 1.410 & $\begin{array}{l}79.6 \\
\%\end{array}$ & $\begin{array}{l}- \\
0.882\end{array}$ & $23.9 \%$ \\
\hline
\end{tabular}

Loan to deposit parameter: From the above table, it is seen that loan is positively correlated in all the regression output with a good significance level. So, deposit is a good estimator of loan and has a significant impact on loan. Loan to Cash in Hand parameter: Cash in Hand is negatively correlated in four regression results except EXIM Bank. But the significance level is very high in most of the output. So, CIH cannot explain completely the amount of loan disbursement.

Loan to Balance with Other Banks: BWOB is negatively related with loan in three of the total five outputs. In two outputs the relationship is positive. In these results, the significance level is also considerable. That's why the BWOB cannot perfectly explain the nature of loan.

\section{IMPACT OF LOAN CLASSIFICATION ON ECONOMIC DEVELOPMENT}

Credit facilities of banks maintain a crucial role in the development of the economy of Bangladesh. Industrial sector is largely dependent on the assistance of the banking loan and services. At this time of reducing the demand of credit facilities by the private investors the liquidity position of the banking sector is increasing rapidly. The current incompetence in the banking sector can partly be featured to incarcerate governance and omission. Poor management system, poor supervision over the bank, robust political situation and violence of political power in this sector are deterioration the condition. As a result, the growth of loan facility in all sectors has declined. If this situation continues in some following years then it will be an alarming issue for our economy.

Banks are maintaining higher position of provision for increasing the amount of classified loans and fulfilling the requirement of Bangladesh Bank. This increases the possibility of default of that bank. As a result potential customer cannot get adequate loan for their necessities. On the other hand, decreasing the profitability reduces the revenue of the government of Bangladesh from the banking sector. Decreasing the level of demand of credit facilities increases the liquidity of the banking sector. Private sector's investment decreases rapidly. Bangladesh Bank raises the Cash Required Requirement (CRR) from 5.5 present to 6 present for reducing the excess amount of liquidity position and decreasing the inflation of the economy.

Government borrowing is increasing from the banking system day by day. For this reason the bank will face the shortage of fund to provide loan to the potential sectors. Higher classified loan decreases income of the bank which requires high degree of provision. It decreases the investment and the growth of economic. Relatively poor management, lack of transparency, weak roles and supervision, minimum interest rate spread and robust political situation are responsible for non-performing loan. 
That's why it decreases the growth of the economy. From the last few years countries socio-economic development is largely dependent on the loan disbursement of the banking sectors.

\section{PROBLEMS OF NON-PERFORMING LOANS (NPL)}

Problems of NPL are such as Stopping Money Cycling, Earning Reduction, Capital Erosion, Increase in Loan Pricing, Frustration etc. As a result, the values of security are increased and the risks of financial recession also see a rise. Amplifications of the effect of NPL are as follows:

- Non-performing loan escorts to the effectiveness problem for the banking sector. Banks do not optimize their assortment resolutions by lending less than demanded.

- Non-performing loans and performance efficiency are inversely related. So, increase in NPL hampers the performing loan. Most of the cases, it occurs when there is an adverse selection. Averse selection is asymmetric information problem that occurs before the transaction. For example: big risk takers or outright crooks might be the most eager to take out a loan because they know that they are unlikely to pay it back. Because adverse selection increases the chances that a loan might be made to a bad credit risk, lender might decide not to make any loans, even though there are good credit risks in the market place.

- NPL creates the Credit Crunch situation. Credit crunch is an occurrence that banks ration loan disbursement and new credit commitments in order to protect, but add more risks. Banks treat loan as an asset. They expect return from it. If loans become NPLs then banks have lack of fund to give loan according their commitment or banks could give loans at their previous interest rate. Clients have to pay more. So loans may be defaulted. Credit crunch also increases the rate of NPL.

- There is a cyclic relation between poor economic condition and depressed economic growth as follows:

a. During the crisis moment, banks not only endeavor to increase the capital but also diminish their risk assets or modify the masterpiece of the asset portfolio. Because of such suspicious actions, the large borrowers are always targeted, thus the economic growth is being stalled overall. Banks try to collect loans amount as fast as possible and most of the banks have huge number of corporate clients so they try to recover those loans as early as possible to reduce risky assets.

b. Money cycling gets stopped due to increase in NPL. Slow flowing of cash always has negative impact on any business.

c. When the NPL is increased, interest earning gets stopped. But the cost of fund and the cost of management are not stopped. To run the management cost along with the cost of fund, the existing lending price has to be increased. Suddenly increased rate of interest makes hard the return of bank money for a new borrower. So rate of investment will be lower.

d. NPL affects opening of LC (Letter of Credit). International importers always choose healthy condition of the exporter's bank. Worse health condition of the bank affects the opening of new LCs. Low rate of LCs makes low bank earning.

- Banks choose on the scale of risks they will endure for a given level of expected return according to their risk inclination because banks must maintain $10 \%$ of their risk weight asset as capital or 400 cores when banks re-balance their composition of portfolio. Banks treats loans as a risky asset. If the risk is high, banks will expect high return. When the level of classified loans goes beyond a convinced point banks cannot accept, and then it affects bank's rebalancing actions. So, when NPLs cross the boundary of the above threshold, they start to spawn negative effects on more lending.

NPL has a positive relationship with interest rate. When NPL increases, loan which is treaded as asset becomes more risky. So that the rate of interest also increases to get sufficient retune from the loan to cover the risk. 


\section{CONCLUSION \& RECOMMENDATION}

Since 1989, Bangladesh pursues both "overdue criteria" and "qualitative criteria" to estimate a loan classified or unclassified. All loans are divided into five categories such as continuous loan, demand loan, term loan payable within five years, term loan payable in more than five years and short-term agricultural credit or micro credit. All default loans are also reclassified as special mention account (SMA), substandard, doubtful and bad/losses. In order to maintain the management up to date about the status of loans, bank managers review the loan quality on daily basis. With some exclusion, the banking sector at present pursues a norm of six months overdue for estimating a loan nonperforming. The rate of provision on classified loans follows norms of $5 \%, 20 \%, 50 \%$ and $100 \%$ against special mention accounts, substandard, doubtful, and bad/loss loans respectively. So as we see in our regression analysis that the amount of classified loan increases as total loan increases and at the same time profit also increases as because profit and total loan are positively related. So for maximizing profit we should decrease the amount of classified loan.

The banking sector of Bangladesh is illustrated by low profitability and insufficient capital base because there are lots of banks in Bangladesh. Banks revenue comes from spread (Lending rate borrowing rate).But there is huge competition among banks. So the profit of these banks is minimum. The bottom line of the problem smears in the accumulation of high percentage of classified loans over a long period of time. The problem is most serious for state owned commercial banks. Classified loan was $41.1 \%$ in 1999 which was gradually reduced to $11.90 \%$ in 2013 according to latest published data. Bangladesh has had a two-decade long experience in dealing with loan classification problem. Regrettably, the banking system is burdened with huge amount of classified loans and insulates far behind the adjoining countries of India and Sri Lanka. Bangladesh follows a large degree of international standards of loan classification and provisioning. The management system of classified loans is found unproductive. It requires to be declared that management of classified loan has to be multi-pronged. Appraises should be in place for both preclusion and declaration. With regard to anticipatory measures, prominence requires to be put on credit screening, loan supervision and loan review functionaries both at individual bank levels and in the central bank of the country. Declaration measures have to be escorted by legal measures. Unfortunately, Bangladesh is found to be very weak from the above point of view and severely speaking. It has mainly contemplated on legal measures that have also been found to be fruitless. However, this research work has emphasized few disputes which are shown below. For progressing the loan recovery environment and solving loan classification problems are also shown below as well.

We are here trying to mention some advices for minimizing the amount of classified loan and for more improvement in these sectors.

- To work out syndicated financing for large loans facility and to diminish the detrimental antagonism among banks in Bangladesh.

- Bangladesh Bank should increase the supervisory power and monitoring functions to control the banks that engage in malpractice.

- Bankers should apply the human skill, diligence, prudence while delivering credit. To ensure this ability of employees, training should be provided. More awareness needs to be developed.

- To increase the ethical standards of the bank officials from all bends to create the credit environment trustworthy and vibrant.

- Identification of highly risk sensitive borrowers in the credit portfolio. Banks should take information about the clients before giving loans. Banks could go Bangladesh Bank to collect the information and verify the financial statement carefully from reliable sources to identify the risky borrowers.

- To increase the explicit techniques to differentiate the intractable defaulters from the indisputable ones.

- Banks should continuously review loan accounts to meet credit requirements of existing borrowers and to take corrective actions to seize the growth of non-performing. 


\section{REFERENCES}

- M. K. Dash, 2010 "The Determinants of Non-Performing Assets in Indian Commercial Bank: An Econometric Study"

- YixinHou, "The Non-performing Loans: Some Bank-level Evidences", Journal of Banking and Finance, 2001, 25-46

- Haneef S. and Riaz T. (April 2012 "Impact of Risk Management on Non-Performing Loans and Profitability of Banking Sector of Pakistan" International Journal of Business and Social Science, Vol. 3 No. Rajan, R. \&Sarat, C. D. 2003. "Non-performing Loans and Terms of Credit of Public Sector Banks in India: An Empirical Assessment" 24(3), 81-121.

- Tracey M., September 2011 "The Impact of Non-performing Loans on Loan Growth: an econometric case study of Jamaica and Trinidad and Tobago"

- Sinkey, J. F. \& Mary B. G. 1991. "Loan-Loss Experience and Risk-Taking Behavior at LargeCommercial Banks" Journal of Financial Services Research, 5, 43-59, CrossRef

- Saba I, Kouser R. \&Azeem M. June 2012 "Determinants of Non-Performing Loans: Case of US Banking Sector" vol. no. 44

- Rahman Q. M. 2012"All about non-performing loan: The Bangladesh scenario"

- Rahman Qazi Mahmudur. et al(2012), " All about Non-performing Loans : The Bangladesh Scenario" The Financial Express, November.

- Lata Rabeya Sultana. et ad.(2013)"Nonperforming loan: A Detriment to sound environment in banking industry" The Daily Sun ,July.

- Banking Sector: Current Status Bangladesh Economic Update December 2013.

- Masoom Mohammad.et al.(2013) "Strategies for recovery of nonperforming loan", The Financial Express, 16 February .

- Mishkin Frederic S. (2011) Financial Markets and Institutions (6th Addition) India Dorling Kindersley(India) PVT. Ltd.

- Rashid Mamun et al(2012) "Debt Default in Banks" Bank Parikrama 